09-008

\title{
Rethinking the Role of History in Law \& Economics: The Case of the Federal Radio Commission in 1927
}

\author{
David A. Moss \\ Jonathan B. Lackow
}




\title{
Rethinking the Role of History in Law \& Economics:
}

\section{The Case of the Federal Radio Commission in 1927}

\author{
David A. Moss \\ Jonathan B. Lackow
}

July 13, 2008

\begin{abstract}
$\underline{\text { Abstract }}$
In the study of law and economics, there is a danger that historical inferences from theory may infect historical tests of theory. It is imperative, therefore, that historical tests always involve a vigorous search not only for confirming evidence, but for disconfirming evidence as well. We undertake such a search in the context of a single well-known case: the Federal Radio Commission's (FRC’s) 1927 decision not to expand the broadcast radio band. The standard account of this decision holds that incumbent broadcasters opposed expansion (to avoid increased competition) and succeeded in capturing the FRC. Although successful broadcaster opposition may be taken as confirming evidence for this interpretation, our review of the record reveals even stronger disconfirming evidence. In particular, we find that every major interest group, not just radio broadcasters, publicly opposed expansion of the band in 1927, and that broadcasters themselves were divided at the FRC's hearings.
\end{abstract}




\section{Introduction}

What is the role of history in the study of law and economics?

Perhaps its most important role in this context is as a test of theory and a source of new hypotheses. Ronald Coase, for example, famously challenged our understanding of public goods by exposing the hidden history of private lighthouses when theory had imagined only public ownership. ${ }^{1}$

History can also be informed by theory. George Stigler once observed that important historical inferences about policy intent could be drawn from the economic theory of regulation. Noting that the "theory tells us to look ... at who gains and who loses, and how much, when we seek to explain a regulatory policy," he suggested that "the truly intended effects [of a policy] should be deduced from the actual effects." ${ }^{2}$ Indeed, inferences of this sort have become common in law and economics. ${ }^{3}$

One significant danger is that these two strategies may become intertwined - that historical inferences from theory may somehow make their way into historical tests of theory. Surely, such inferences cannot legitimately be adduced as evidence for the theory that generated them. To the extent that historical cases are regarded as support for a theory, they must be based on hard evidence, not on inference from the theory itself.

Avoiding this trap is anything but easy, particularly given the powerful hold that certain theories now have within the field. The economic theory of regulation is a good case in point. When we see an interest group benefit from a regulation, it is now almost instinctive to conclude that this was the intended result and that the interest that benefited must have been at least partly - and perhaps wholly - responsible for securing the regulation in the first place (through lobbying, etc.). ${ }^{4}$

One unfortunate consequence with respect to historical inquiry is that researchers may be tempted to scratch around in the documentary record to find what they were looking for - to find what they knew in advance, based on theory, had to be there. To avoid this

\footnotetext{
${ }^{1}$ Ronald H. Coase, The Lighthouse in Economics, 17 J Law \& Econ. 357 (1974).

${ }^{2}$ Stigler, Supplementary Note on Economic Theories of Regulation, in The Citizen and the State 140 (1975) [emphasis in the original].

${ }^{3}$ However, Roger Noll warns of "the lurking danger of tautology, i.e., of attributing causality to an inevitable consequence of any public policy action. It is impossible to imagine that regulation could be imposed without redistributing income. Hence, a look for winners in the process - and organizations that represent them - is virtually certain to succeed.” See Roger G. Noll, Economic Perspectives on the Politics of Regulation, in Richard Schmalensee and Robert D. Willig, eds, Handbook of Industrial Organization, Vol. II, at 1276-1277 (1989).

${ }^{4}$ For example, Thomas Hazlett and Matthew Spitzer write, “One need not assume perfect foresight nor abstract from the transactional difficulties in a political world to conclude that when interests with substantial rents at stake appear to secure optimal regulatory outcomes they were more than lucky. Indeed, George Stigler long held that it made sense to infer backwards...” [Thomas W. Hazlett and Matthew L. Spitzer, Digital Television and the Quid Pro Quo, 2 Business and Politics 115, 129 n.89 (2000)].
} 
trap, it is imperative that the use of history as a test of theory always involve a vigorous search not only for confirming evidence, but for disconfirming evidence as well. Good science requires nothing less.

In this paper, we take up the challenge of using history to test theory by focusing on a single well-known case: the Federal Radio Commission's 1927 decision not to expand the broadcast radio band.

The most widely cited study of this decision was conducted by Thomas Hazlett, who concluded that incumbent broadcasters had succeeded in capturing the Federal Radio Commission (FRC). Drawing especially on a primary historical source, the magazine Radio Broadcast, Hazlett found that incumbent radio broadcasters - who presumably would have suffered from additional competition on an expanded broadcast band - strongly opposed the expansion proposal in $1927 .^{5}$ He also took for granted that the listening public would have benefited from expansion of the band, since it would have gained more choice with respect to broadcasting stations. ${ }^{6}$ The FRC's rejection of the expansion proposal thus represented "a classic regulatory capture, creating significant industry rents that were shared with political constituencies in proportion to their effective influence over policy."”

The fact that a powerful interest group favored a regulatory result that appears ultimately to have benefited it stands as a notable piece of confirming evidence for a capture interpretation. It is also necessary, however, to consider what sorts of historical evidence would contradict this interpretation and whether any such evidence exists.

In undertaking this exercise with regard to the FRC's 1927 decision, we conceived of three potential categories of disconfirming evidence: (1) evidence that a broad range of groups, in addition to broadcasters, opposed expansion of the broadcast band; (2) evidence that at least some incumbent broadcasters did not oppose expansion; and (3) evidence that incumbent broadcasters did not in fact benefit from the FRC's ultimate decision to retain the existing band.

Our review of the historical record, including examination of previously unutilized transcripts of the relevant FRC hearings, produced strong disconfirming evidence in category 1 (in short, that every major interest group, not just radio broadcasters, publicly opposed expansion of the band in 1927); weak disconfirming evidence in category 2 (namely, that the broadcasters who testified at the FRC hearings were about evenly divided between opposition and support for the expansion proposal); and some interesting, but ultimately inconclusive, evidence in category 3 (highlighting the relatively bleak expectations about the long-term profitability of commercial radio as of early 1927).

\footnotetext{
${ }^{5}$ See Thomas W. Hazlett, The Rationality of U.S. Regulation of the Broadcast Spectrum, 33 J. Law \& Econ. 133, 154-158 (1990). See also Thomas W. Hazlett, Physical Scarcity, Rent-Seeking and the First Amendment, 91 Col. L. Rev. 905, 918-919 (1997); Thomas W. Hazlett, Underregulation: the Case of the Radio Spectrum, in Thomas W. Bell, The Regulators' Revenge 92 (1998).

${ }^{6}$ Rationality, pp. 155-156.

${ }^{7}$ Hazlett, Physical Scarcity 918-919.
} 
We also searched for additional confirming evidence of a capture interpretation, particularly for direct evidence of attempts by incumbent radio broadcasters to influence FRC commissioners, but found very little evidence of this type.

Overall, we conclude that the disconfirming evidence outweighs the confirming evidence in this case and thus that the 1927 episode cannot reasonably be taken as support for capture theory.

The remainder of the paper proceeds as follows: first, we summarize the logic and evidence behind the traditional argument that the FRC's expansion decision was captured by incumbent broadcasters; second, we provide a brief overview of our argument and key historical findings, most of which run contrary to the capture interpretation; and third, in two consecutive sections that comprise the bulk of the paper, we review the relevant historical evidence (including the state of radio in 1927 and the positions of the major interest groups on the expansion decision) in considerable detail. Finally, in the conclusion, we discuss the implications of our findings and offer some additional thoughts about the proper role of history in law and economics.

\section{The Traditional Story: Capture of the Expansion Decision}

The story of the expansion decision culminates on April 5, 1927, when the Federal Radio Commission (FRC) rejected a proposal that would have expanded the 96-channel radio broadcast band to include the 50 adjacent higher frequency channels, enlarging the 550 to $1500 \mathrm{kHz}$ band to include the 1500 to $2000 \mathrm{kHz}$ band. At the time, nearly all observers believed that the airwaves were overcrowded. Over 700 stations across the country were broadcasting simultaneously on the allotted 96 channels, resulting in significant interference. Enlarging the broadcast band would have allowed the retention of all existing stations, and also would have given new broadcasters a share of the broadcasting landscape. Hazlett argues that by rejecting the expansion proposal, the FRC displayed a clear preference for the anti-competitive interests of incumbent broadcasters over the interest of consumers (listeners) in a larger choice of stations.

In Hazlett's view, no reasonable, impartial regulator could have made such a decision: "If regulators had made a good-faith, even if analytically unsophisticated, attempt to deal straightforwardly with overcrowding of the airwaves, their first step should have been to allow for an expansion of available broadcasting frequencies." Hazlett maintains that no technological barrier blocked the use of those channels. In fact, a band 60 times larger than that assigned to broadcasters was "known to be potentially available given then current technology,” having already been assigned for other communications uses. ${ }^{9}$

The "radio industry's argument" for artificially limiting this nearly boundless terrain was that expansion would harm consumers with first generation radios, by forcing them to buy new receivers. This "transparently false" argument, as Hazlett characterizes it,

\footnotetext{
${ }^{8}$ Rationality 155-156.

${ }^{9}$ Rationality 155-156.
} 
misrepresented the gains from expansion: "Clearly, consumers would be better off having a choice between listening to an uncluttered one- $\mathrm{MHz}$ band on an existing radio and purchasing a broader-band receiver so as to enjoy enhanced program selection, than in being given only the first alternative." 10

Hazlett offers evidence for the broadcasters' position on spectrum expansion by quoting from the "trade journal" Radio Broadcast. ${ }^{11}$ He observes that "the industry was most concerned about how the FRC would deal with 'such dangerous propositions as the pressure to extend the broadcast band...; the fatuous claims of the more recently licensed stations to a place in the ether; and the uneconomic proposals to split time on the air rather than eliminate excess stations wholesale...,' as one trade journal forthrightly summarized.” He quotes from the same journal to highlight the broadcasters' relief and satisfaction once the commission had rendered its decision: "'Broadening of the band was disposed of with a finality which leaves little hope for the revival of that pernicious proposition; ... the commissioners were convinced that less [sic.] stations was the only answer.,"12

\section{A New Look at the Historical Record: The Presence of Disconfirming Evidence}

Although the traditional story of why the FRC rejected the proposal to expand the broadcast band in 1927 seems logical (and fully consistent with the economic theory of regulation), a thorough review of the available documents - including newly rediscovered transcripts of the FRC's hearings on the subject in late March and early April of 1927 reveals a surprising amount of disconfirming evidence not previously presented.

\subsection{A Broad Coalition Against the Expansion Proposal}

To begin with, radio broadcasters were neither the only, nor the staunchest, opponents of expansion. In fact, almost every interest group represented at the hearings opposed expansion, leading the Washington Post to run a story under the headline, "Radio Witnesses Unanimous Against Wider Wave Bands."13 These opponents included not only radio broadcasters, but also radio engineers (who claimed that the proposed frequencies were inferior for broadcasting and that designing new radios to receive those frequencies would prove complicated and costly), radio manufacturers (who shared the engineers' concerns and expressed an unwillingness to antagonize their customers by supporting a

\footnotetext{
${ }^{10}$ Rationality 155-156.

${ }^{11}$ Rationality, 154.

12 Rationality, 155.

${ }^{13}$ Washington Post, March 30, 1927, at 4. In a Columbia Law Review article, Hazlett reaffirmed his claim that “[r]adio broadcast interests bitterly opposed” the proposal to expand the broadcast band by citing the FRC's 1927 annual report, which "noted that '[u]nited opposition to widening the broadcasting band in order to accommodate more stations was expressed at the hearings by representatives of the radio art, science, and industry...”' [Hazlett, Physical Scarcity, Rent Seeking, and the First Amendment, 918 and 918-919n45]. Clearly, though, in using the phrase "representatives of the radio art, science, and industry," the commission meant to cover multiple interests associated with radio (engineers, amateurs, manufacturers, etc.), not just broadcasters.
} 
decision that would render existing radios obsolete), amateur radio operators and inventors (who did not want to lose access to the proposed frequencies, in part because they believed their early experimentation with television had to take place on those frequencies), and representatives of radio listeners' organizations (which echoed concerns about higher-cost radios and lower-quality reception associated with the expanded band and which apparently preferred a smaller number of high quality stations to a larger number of low quality ones). ${ }^{14}$ Given the broad alignment of interests against the proposal to expand the band, it would have been shocking indeed had the FRC decided in favor of it. ${ }^{15}$

\subsection{Broadcasters Were Divided}

Perhaps most surprising of all, the group that was weakest in its opposition to expanding the broadcast band - or at least expressed the most ambivalence about the outcome - comprised the broadcasters themselves. Although one might dismiss such ambivalence as merely a clever exercise in positioning, allowing the broadcasters to hide their true motives from the public, there is reason to believe that their ambivalence was sincere. The biggest player in the broadcasting business, NBC, owned relatively few stations itself and received a significant part of its revenue from selling network programming to other stations. For NBC, therefore, a broader band - and thus more stations - could potentially have meant increased demand for its primary product.

Hazlett, it turns out, may have inadvertently mischaracterized the intensity of the broadcasters' position by misinterpreting a source. Specifically, the "trade journal" that he cited in characterizing the position of the broadcasters - Radio Broadcast - was not in fact a broadcasters' trade journal in 1926-27, but rather a radio enthusiasts and listeners'

${ }^{14}$ While some speakers at the 1927 hearings referred to having received “invitations," Herbert Hoover's assistant observed in a letter at the time that "the Radio Commission has sent out a blanket invitation to all people in the country who desire either to appear in person or to submit their recommendations in writing. I do not understand that the Commission has sent for any particular individuals, however" [Letter from George Akerson, assistant to Sec. Hoover, to Mrs. James T. Rourke, Box 497, Commerce Period Papers, Herbert Hoover Presidential Library (March 29, 1927)].

${ }^{15}$ In documenting this consensus opinion against expansion, we focus below mainly on the views expressed by the various interests (manufacturers, broadcasters, amateurs, listeners, etc) prior to the announcement of the FRC decision. However, we also reviewed coverage in six major newspapers (the Atlanta Constitution, the Chicago Tribune, the Los Angeles Times, the New York Times, the Wall Street Journal and the Washington Post) in the month following the decision. Significantly, none of these papers expressed opposition - or reported on any opposition - to the decision during this period. For example, a New York Times editorial on ways to deal with the interference problem did not object to limiting the band. Instead it repeated, without comment, the arguments that to widen it would encroach on "necessary forms of radio communication" and would force "millions of radio sets" to be rebuilt (The Radio Dilemma, NY Times, April 4, 1927, p. 22). Another article equated widening the band with "invading air channels now used by amateurs" (Asks City Control of Broadcasting, NY Times, April 5, 1927, p. 32). A later article in the Times reiterated the fears of “junking ... millions of dollars' worth of radio receiving sets built to operate on the present broadcasting band," and added that setting the band aside for experimentation was intended to "encourage radio development and with a view to effecting television” (Wave Band Taken to Aid Television, NY Times, April 6, 1927, p. 1). Other newspapers produced similar coverage. See e.g. Amateurs of Radio to Protect Wider Wave-Length Band, Washington Post, Mar 27, 1927, p. 15; Alfred P. Reck, Radio Men Hear Simple Remedy, Atlanta Constitution, March 29, 1927, p. 1; Frank Hinman, Chicago Daily Tribune, Mar 30, 1927, p. 16; Hearings to End Chaos, Los Angeles Times, Mar 30, 1927, p. 1; Air Rights of Way, Los Angeles Times, April 6, 1927. 
magazine. In October 1926, the publication referred to its own typical reader as "Mr. Average Radio Enthusiast" and "Mr. Average Listener."16 The passages that Hazlett quoted from the publication thus reflect not broadcaster opposition, but rather (if anything) listener opposition to spectrum expansion. (For a detailed assessment of Radio Broadcast and its readership, see the appendix below.)

\subsection{Expected Broadcaster Rents May Have Been Smaller than Assumed}

Another possible explanation for the ambivalence of certain incumbent broadcasters is that less may have been at stake than is now commonly believed. In early 1927, radio advertising was still in its infancy, and broadcasting was not yet viewed as a particularly profitable endeavor (and, in a great many cases, as a loss-making endeavor). As a result, the rents that incumbent broadcasters are thought to have been seeking at the time may not have provided them with as strong a motivation to oppose expansion as one might assume in retrospect (i.e., based on a current understanding of the profitability of broadcasting).

\subsection{What Comes Next: A Detailed Review of the Evidence}

The next two sections of the paper presents this new evidence in detail. We begin with a brief portrait of radio circa 1927, which suggests that the broadcasters' incentive to restrict entry may not have been nearly as strong at the time as one might now assume from a modern vantage point. We then review the positions of each of the major groups with an interest in the broadcast band - radio engineers, radio manufacturers, radio broadcasters, amateur operators and experimenters, and radio listeners. This reveals (1) that all of the major groups opposed the expansion proposal in 1927 and (2) that the broadcasters were less united on the subject than has been reported in the literature. Finally, in the conclusion, we offer an overall assessment of the evidence in this case as well as some general observations about the use of qualitative history in hypothesis testing and the importance of vigorously searching for disconfirming - as well as confirming - evidence in the historical record.

Although the historical evidence presented in the pages that follow is offered in considerably greater depth than is typical outside of a history journal, we believe such granularity (and attention to primary sources) is essential if history is to be used credibly as a test of theory. As almost any criminal lawyer will attest, critical details can easily be misinterpreted from a distance - with bias and presumption gradually replacing true observation as distance increases. It is for this reason that, after summarizing the argument and evidence above, we now move on to take a closer look at the evidence (and the surrounding historical context) in the sections below.

\footnotetext{
${ }^{16}$ See Kingsley Welles, Meet Mr. Average Radio Enthusiast, 9 Radio Broadcast 531 (October 1926).
} 


\section{A Portrait of Radio, Circa 1927}

In 1927, radio was, if not in its infancy, at least still in its early childhood, and modern broadcast advertising had barely been conceived. As a result, inferences about the 1920s radio industry based on present circumstances (or even those of radio's golden age in the 1930s and 1940s) are likely to prove far off the mark. An accurate characterization of radio during the early days of the FRC is essential in setting the context for the expansion story and thus in laying the foundation for a serious historical examination of the FRC's decision.

\subsection{The Radio Landscape}

The traditional birth date of broadcasting is November 2, 1920. On that day, the Pittsburgh station KDKA broadcast news of Warren G. Harding's victory in the presidential election, transmitting on its 100-watt set from six o'clock in the evening until noon the next day. ${ }^{17}$ More than a thousand broadcasters entered the field over the next six-and-a-half years, such that by the time the FRC was formed in 1927 there were 733 stations vying for the 96 channels between 550 and 1500 kilohertz. $^{18}$

In the intervening years, radio had grown from fad to national habit. One radio retailing journalist estimated that in 1927 there were 6.5 million homes with radio sets, playing to an audience of 25 million. ${ }^{19}$ Major newspapers published daily radio schedules, and Secretary of Commerce Herbert Hoover had already held four national conferences on radio broadcasting. In less than a decade, radio had catapulted from an amateur fixation to a matter of national importance.

But radio in 1927 bore only incipient resemblance to today's advertising-driven 24hour network television and radio programming, or to the golden age of radio in the popular imagination. Most commercial stations broadcast at between 250 and 1000 watts of power (a miniscule amount compared to today's many 50 kilowatt stations) with a range of approximately 10-20 miles. ${ }^{20}$ Universities, churches, and other non-profit organizations primarily operated "local" stations, with service for only a few surrounding miles, but many general interest broadcasters also operated locally.

While we often associate early radio with dramatic serials, radio drama had not fully developed by 1927. In fact, music dominated from the beginning. A 1925 survey shows that over 70 percent of radio content was live music, followed by informational broadcasting (including education and news) at 12 percent, with drama (mostly play readings) at one-

\footnotetext{
${ }^{17}$ Christopher N. Sterling and John Michael Kittross, Stay Tuned 66 ( $3^{\text {rd }}$ ed. 2002).

${ }^{18}$ Lawrence Frederick Schmeckebier, The Federal Radio Commission 23 (1932). Six of these channels had, by agreement, been reserved for Canadian broadcasters.

${ }^{19}$ Orestes Caldwell, The Radio Market, in Radio and its Future 206 (1930).

${ }^{20}$ For power and distance figures, see Conference Held at Washington, D. C., starting Tuesday, March 29, 1927 before the Federal Radio Commission: Minutes 93-94 (unpublished transcript, Herbert Hoover Presidential Library, April 1927). For overall power ratings, see Department of Commerce, Commercial and Government Radio Stations of the United States (1927).
} 
tenth of one percent. ${ }^{21}$ The weekly radio program guide in the New York Times for March 27, 1927, suggests that broadcasting remained highly skewed toward music as the FRC was being established. ${ }^{22}$

Network programming was still novel. Even network affiliates produced much of their programming locally, and these stations often switched to their network feed only in the evening hours. ${ }^{23}$ The only major network as of early 1927 was the National Broadcasting Company (NBC), which first went on the air on November 15, $1926 .{ }^{24}$ It was the child of "big radio" from the outset, with General Electric and Westinghouse each owning 25 percent, and the behemoth Radio Corporation of America (RCA) owning the remaining 50 percent. $^{25}$ NBC was born when the conglomerate purchased the WEAF-based network that AT\&T had been operating since 1924, added that network to RCA's own WJZ-based network, and connected all 19 stations with AT\&T’s telephone lines. ${ }^{26}$

The network was first and foremost a content provider rather than a station owner. When the radio commission was established, NBC still owned only WEAF directly, and the combined holdings of NBC, RCA, GE, and Westinghouse amounted to only ten stations out of 733. ${ }^{27}$ NBC's two primary sources of income were revenue from nationally sponsored programs and fees collected from local affiliates for its unsponsored or "sustaining" programs. ${ }^{28}$ But even NBC was a new-comer to the sponsorship game: as late as September 1926, the RCA network did not accept payment for the "indirect advertising programs" they broadcast, merely transmitting sponsor-produced programs at no charge to the sponsors. ${ }^{29}$

\subsection{The Role of Advertising in Early Radio}

As late as the mid 1920s, even the most thoughtful scholars and journalists were unable to predict the dominant role that advertising would play in radio broadcasting by the start of the next decade. In fact, throughout much of the 1920s there was no consensus that broadcasters would be able to sustain their operations without outside support.

\footnotetext{
${ }^{21}$ Sterling and Kittross, Stay Tuned, 81.

22 Radio Programs for Current Week, N. Y. Times, March 27, 1927, at 21. While this listing does not include the smallest stations broadcasting in the New York area, it does represent many of the stations an average set in Manhattan could receive.

${ }^{23}$ Note, however, that because often listeners tuned in only after supper, many stations broadcast solely during evening hours, leaving their assigned frequencies idle for the remainder of the day.

${ }^{24}$ Sterling and Kittross, Stay Tuned, 117.

${ }^{25}$ RCA itself was founded by GE, which retained with Westinghouse a plurality ownership of RCA shares.

26 The early days of radio, Museum of American Heritage: When Radio Was King exhibit, http://www.moah.org/exhibits/archives/radio/earlydays.html, visited November 3, 2003.

27 These stations were Westinghouse's KDKA, KFKX, KYW and WBZ; GE's KGO, KOA and WGY; RCA's WJZ and WRC; and NBC's WEAF. See Commerce, Radio Stations.

28 Sustaining Program, Museum of Broadcast Communication Encyclopedia of Television, http://www.museum.tv/archives/etv/S/htmlS/sustainingpr/sustainingpr.htm, visited November 3, 2003.

${ }^{29}$ Austin C. Lescarboura, How Much it Costs to Broadcast, 9 Radio Broadcast 367-371 (1926).
} 
Hiram Jome's extensive 1925 study, Economics of the Radio Industry, repeatedly returns to "the "who shall pay' problem." 0 Jome estimated that radio broadcasting was bound to be unprofitable, since the "few sources of income, such as paid advertising," would be unlikely to cover the considerable expenses of a commercial station (including normal operating expenses, royalties, and so forth). ${ }^{31}$ The discrepancy seemed so obvious that Jome proposed a tax on radio manufacturers' sales to make up the difference. ${ }^{32}$

But if the average radio station was not expected to pay for itself, then why were so many stations established in the twenties? Some owners, presumably, expected to beat the average. Others, perhaps, were not primarily interested in making money. By our count, one-quarter of stations in 1927 were non-profits, ranging from religious stations to agricultural information stations to university stations. ${ }^{33}$

Many for-profit owners, meanwhile, sought to make money only indirectly. According to Radio Broadcast, these included "individual publicity stations operated by department stores, newspapers, radio companies, and other commercial institutions for the purpose of building good will for the owner, but not accepting outside pay for broadcasting." ${ }^{34}$ In fact, the first (and probably most prominent) station owners during the 1920s were radio manufacturers, who initially entered broadcasting to boost demand for their receivers. $^{35}$

Perhaps most striking of all from a modern vantage point, paid advertising as we know it today was not originally regarded as an ideal or dominant financing mechanism for broadcasting. In fact, direct advertising over the airwaves was practically an afterthought in

\footnotetext{
${ }^{30}$ Hiram Jome, Economics of the Radio Industry 183 (Chicago: A. W. Shaw \& Co. 1925). See also Susan Smulyan, Selling of Radio: The Commercialization of American Broadcasting 1920-1934, esp. Ch. 3 (1994).

${ }^{31}$ Jome, Economics of the Radio Industry, 253-254.

32 Jome, Economics of the Radio Industry, 254-255. Also reflecting concern about radio's financial future, Radio Broadcast offered a $\$ 500$ prize in March of 1925 to the best plan for funding broadcasting. The winning idea was a proposal for a receiver tax reminiscent of the BBC's. David Sarnoff himself advocated "philanthropic donations to support radio" in 1926, the same year that a GE spokesman predicted that broadcasting would eventually be supported by either "voluntary contributions or receiver licenses," according to Sterling and Kittross, Stay Tuned, 80.

${ }^{33}$ To produce our estimate of the proportion of non-profit stations, we looked at the names of station owners that are listed in the Commerce Department's guide to U.S. radio stations for 1927. Assuming stations owned by such organizations as the First Baptist Church of Shreveport, Louisiana, or the South Dakota State College were non-profits, we counted 170 non-profits out of a total of 694 stations listed. See Department of Commerce, Commercial and Government Radio Stations of the United States, 72-92 (1927).

${ }^{34}$ Austin C. Lescarboura, How Much it Costs to Broadcast, 9 Radio Broadcast 367-371 (1926).

${ }^{35}$ As RCA's David Sarnoff wrote, "When the radio industry outgrew its first customer - the radio amateur the electrical industry of the United States undertook to create a listening public" [David Sarnoff, Art and Industry, in Radio and its Future 187 (1930)]. Similarly, the Wall Street Journal announced to its readers in November 1926 that RCA, "with its subsidiary company, the National Broadcasting Co., is preparing better and bigger programs, and this is the key to increased sales of radio sets" [Radio Having Biggest Year, Wall St. J., Nov. 2, 1926, at 9]. Not everyone agreed, however, that increased radio sales would be sufficient to support broadcasting. One contemporary radio commentator declared in September of 1926 that "no manufacturer and not even a group of manufacturers could afford to broadcast throughout the entire country day in and day out in return for the sale of radio receivers and radio accessories” [Lescarboura, How Much It Costs].
} 
the minds of many broadcasters. When Jome asked a sample of 69 broadcasters in 1925 their purpose in broadcasting, only two responded that even their secondary purpose was "to profit by direct sale of advertising time."36 Part of the reason for this may have been that direct advertising - the explicit discussion of products that we recognize as advertising today - was often viewed by the public as distasteful in the 1920s. The 1925 National Radio Conference, organized by Herbert Hoover, held that "both direct and mixed advertising were objectionable to the listening public." ${ }^{\prime 3}$ In 1927, a representative of the United States Radio Society, which identified itself as a listeners' organization, told the FRC that it had "received many communications of protest against the use of the air as a means of direct advertising. The opposition to this type of broadcasting has been so strong that the society has recently started a campaign against this evil."38

An alternative form of advertising involved indirect or "good will" advertising, similar to today's PBS underwriting, in which the sponsor's name would appear in the program's title - the Everready and Atwater Kent Hours were prominent examples - or in brief mention at the end of the program. The sponsors' products were also likely to figure in the programs themselves. ${ }^{39}$ While listeners came to accept these indirect advertisements, even this was only grudgingly conceded in many cases. ${ }^{40}$

What little we know of radio finances in the 1920s only reinforces this picture of financial uncertainty. ${ }^{41}$ Even by our most conservative estimate, regular operating costs in

\footnotetext{
${ }^{36}$ Jome, Economics of the Radio Industry, 168.

${ }^{37}$ Proceedings of the Fourth National Radio Conference and Recommendations for Regulation of Radio, November 9-11, 1925, issued by the Government Printing Office in Washington, D.C. for the Department of Commerce (1925).

${ }^{38}$ Minutes, April 1, 1927, 354. In a review of listeners' organizations in its July 1927 issue, Radio Broadcast characterized the United States Radio Society as the "most promising [listeners'] organization from which we have heard” [Where Are the Listeners' Organizations, 11 Radio Broadcast 141 (July 1927)]. Although RCA's Alfred Goldsmith had determined by 1925 that "there is no way in which the Radio Corporation could secure such financial returns [as AT\&T] outside of the advertising business," he expressed concerns that advertising would mean that "the good will of the broadcast listener ... might be jeopardized," hurting the company's radio sales. A. Michael McMahon, The Making of a Profession: A Century of Electrical Engineering in America 163 (New York: IEEE Press 1984).

${ }^{39}$ Sterling and Kittross, Stay Tuned, 80; Smulyan, Selling Radio, esp. Chap. 3. Interestingly, corporate underwriting of this sort - though clearly the dominant form of radio advertising at the time - was only part of what Austin Lescarboura, a writer for Radio Broadcast, had in mind when he announced in 1926 that "the sponsored program is the solution to the old, old question, 'Who will pay for broadcasting?'” Whether it was the First Baptist Church or RCA or Everready, someone was always willing to pay. "[T]hey have one point in common," Lascarboura observed, "they are all bent on selling something, whether it be a product or a religion, agricultural ideas or interest in economics, better voice transmission, or the name of the owner." Austin C. Lescarboura, How Much it Costs to Broadcast, 9 Radio Broadcast 367-371 (1926). Such an expansive notion of sponsorship - which sounds so quaint today - accurately reflects the still-primitive state of radio advertising just one year before the establishment of the FRC.

${ }^{40}$ In a morbidly comic cartoon from 1928, a listener subject to too many sponsor announcements bombs his local radio station. The Events Leading Up to the Tragedy, N. Y. World (September 19, 1928), reprinted in Smulyan, Selling Radio.

${ }^{41}$ A monograph on radio advertising written in 1934 found that a full tally of profits was only possible beginning in 1931, adding in a footnote that "an attempt to do this [before 1931] was abandoned upon advice of experts, because of the chaotic state of many station books even in recent years, and because the turnover of
} 
broadcasting in 1927 exceeded total advertising revenues, which have been estimated at \$4.8 million that year. ${ }^{42}$ In a February 1927 speech, RCA president James G. Harbord told the company's trustees, "We are breaking even in our national broadcasting proposition. We had no thought of making money in this venture, but we wanted to give the public the best possible radio program and I think we have succeeded in doing this. If we continue to break even I will be more than satisfied.”43

In retrospect, it seems that this environment was beginning to change in 1927, at least with respect to radio advertising. In a July 8, 1928 speech at the International Advertising Convention, NBC's Frank Arnold declared that just eighteen months before (i.e., in early 1927), "the attitude of the advertising agents of the country toward Broadcast Advertising was either negative or indifferent.... Nowhere along the agency line was there any marked enthusiasm, to say nothing of general acceptance." ${ }^{\prime 4}$ But, according to Arnold, that indifference had finally given way to genuine interest roughly six months later - in mid 1927 - when "Radio Broadcasting was recognized as an advertising medium by the International Advertising Association." 45 Similarly, Sterling and Kittross suggest that "it was not until 1928 that broadcast advertising clearly became the breadwinner for American radio broadcasting”"46 - one year after passage of the Federal Radio Act on February 23, $1927 .{ }^{47}$

On the eve of broadcast regulation, therefore, the radio landscape and the financing of radio both dramatically differed from what we might expect, given our current assumptions about the economics of broadcasting. Back in 1927, networks were still relatively new and immature. Live music broadcasts dominated the dial. Direct advertising (now practically the universal mode of financing radio) had few supporters. There was no consensus about how, or whether, broadcasting would ever be profitable. Thus, in considering the incentives of various radio interest groups at the dawn of the Radio Commission, it may not be appropriate to assume that commercial broadcasters anticipated the sort of rents that would later accrue to them as advertising matured.

station ownership further complicated the matter" [Herman S. Hettinger, A Decade of Radio Advertising 108 (Univ. Chicago P, 1934)].

${ }^{42}$ The 1951 Yearbook issue of Broadcasting magazine estimated that, for the entirety of 1927, advertising expenditure on radio totaled $\$ 4.8$ million, with $\$ 3.8$ million of that going to national networks. To put this figure in some perspective, it is worth noting that sales of radio sets were widely estimated to have totaled \$168 million that year [Caldwell, The Radio Market]. Our rough estimate of total operating costs for broadcasting in 1927 ranges from $\$ 5.7$ million to $\$ 18.3$ million; it is based on Jome’s 1924 survey of broadcasters, at $174-175$, suggesting that average annual costs ranged from a lower bound of $\$ 7800$ to an upper bound of $\$ 24,900$ that year (not including installation expenses) and the fact that there were 733 stations in operation in 1927.

${ }^{43}$ Promising Radio Year Predicted by Harbord, Wall St. J., February 7, 1927, at 16.

${ }^{44}$ Frank A. Arnold, Popular Reactions to Radio Broadcasting 13 (National Broadcasting Company 1928).

${ }^{45}$ Frank A. Arnold, Popular Reactions to Radio Broadcasting, 5.

${ }^{46}$ Sterling and Kittross, Stay Tuned, 80.

${ }^{47}$ Jome signed and dated his preface on August 18, 1925. Jome, Economics of the Radio Industry, vii. 


\subsection{The Federal Radio Commission}

The Radio Commission itself, which was created under the Radio Act of 1927, succeeded the Commerce Department, which had previously exercised authority over radio based on the Radio Act of 1912. The 1912 legislation, ostensibly aimed at regulating amateur radio operators, had passed in Congress after amateurs interfering with ship distress signals impeded rescue efforts to save survivors of the Titanic disaster. Although the 1912 act did not explicitly cover broadcasting, Herbert Hoover's Commerce Department assumed that it had the authority to grant broadcast licenses and continued to believe this through 1926. Having convened a series of National Radio Conferences from 1922 to 1925, Commerce followed the resulting recommendations in (1) limiting broadcasting to the 550 $1500 \mathrm{kHz}$ band, (2) separating broadcast stations by at least $10 \mathrm{kHz}$, (3) preferring highpower national stations to local low-power ones, and (4) awarding a limited number of free licenses to stations on the grounds of service to the public interest - all prominent features of what would become the FRC regime. ${ }^{48}$

A period of "chaos" began when Commerce attempted to deny the Zenith Radio Corporation the right to broadcast on the $910 \mathrm{kHz}$ channel. Unhappy with the crowded 930 $\mathrm{kHz}$ channel that it had been allotted, Zenith ignored Commerce and "jumped" to the 910 channel in December 1925. Although Hoover's Commerce Department sued Zenith, the courts ruled the following year that Commerce had no power to refuse requests for broadcast frequencies. Apparently acting on advice from the Attorney General, who concurred that the 1912 Act "provided no criteria for licensing," Hoover chose not to appeal. $^{49}$

With Commerce now effectively on the sidelines, hundreds of incumbent stations proceeded to jostle for better frequencies and time assignments, and hundreds of new stations entered on existing and intermediate channels. This caused considerable interference - far worse than the typical static that today's AM listeners still hear. Radio Commissioner Orestes Caldwell subsequently described the interference as being "so bad at many points on the dial that the listener might suppose instead of a receiving set he had a peanut roaster with assorted whistles." ${ }^{\text {0 }}$ Although Congress had considered over 50 radio bills since 1921, the outbreak of chaos on the airwaves was apparently enough to provoke it finally to pass one - the 1927 Radio Act - in February of that year. ${ }^{51}$

The primary innovations of the new Radio Act were the creation of an independent commission, the FRC, with the authority to regulate the radio spectrum and to license broadcasters, and the assertion that radio frequencies were inalienable public property, to be dispensed according to "public convenience, interest, or necessity." 52 While the original 1927 legislation established the commission for only one year, in order to clear up the

\footnotetext{
${ }^{48}$ Sterling and Kittross, Stay Tuned, 97.

${ }^{49}$ Robert W. McChesney, Telecommunications, Mass Media, and Democracy 16.

${ }^{50}$ Annual Report of the Federal Radio Commission for the Fiscal Year Ended June 30, 1927 at 11 (1927).

${ }^{51}$ Bensman, Beginning of Broadcast Regulation, at 208.

${ }^{52}$ Radio Act of 1927, 47 U.S.C. § 4 (repealed 1934).
} 
"chaos," the FRC was renewed annually until the 1934 Communications Act replaced it with the permanent Federal Communications Commission. ${ }^{53}$

In passing the 1927 act, Congress had worried a great deal about the threat of concentrated control over the broadcasting spectrum, especially given the extraordinary political significance of radio. ${ }^{54}$ Presumably, its decision to vest control of all frequencies with the federal government (and to prohibit private ownership of the spectrum) was seen as a sufficient response to that threat, preventing any individual or group from buying up a large number of stations and thus obtaining (and exercising) undue political influence. Having taken control of the spectrum, however, the federal government simultaneously assumed responsibility for managing it. And this is where the FRC came in. By all accounts, the commission's primary mission was to clean up the airwaves - to make order out of the chaos.

Accordingly, the FRC's battle cry was “an end to interference.” Chairman Eugene Sykes told the House that "the commission understands, under the law, that the dominant intent and purpose of that law, so far as the broadcasting situation is concerned, which we understood was the most acute problem then confronting the commission, it is [sic.] our duty to try and ensure good radio reception to the listening public." 55 Henry Bellows, another commissioner, was just as explicit during the first public hearings, saying: "You all know what the immediate problem before the Commission is - the problem of reallocating and re-arranging the wave lengths within the broadcasting band so as to eliminate, or at any rate greatly reduce, the amount of interference between stations." ${ }^{\text {, }}$

To that end, the FRC called public hearings from March 29 to April 1 of 1927 in order to solicit and evaluate ideas for how best to manage the broadcasting spectrum. As Commissioner Bellows explained at the outset of the initial session, a proposal for "widening of the broadcast band" was taken up first "because, obviously, in working out the policies of the Commission it is going to be necessary to determine first of all whether the only channels available for broadcasting are the channels now assigned to this service, or whether, from the standpoint of the listener, the broadcaster, the manufacturer, and the users

\footnotetext{
${ }^{53}$ Because the Radio Act was passed during the short session of the 1927 Congress, there was no time to make full appropriations for the Commission, or even to confirm (and thus give salaries to) two of the five commissioners. See Louis Caldwell, Testimony before Senate Interstate Commerce Committee 67 (vol. 1, May 1929).

${ }^{54}$ Moss and Fein, Radio Regulation Revisited: Coase, the FCC, and the Public Interest, 15 J. Policy History 389 (2003).

55 Jurisdiction of Radio Commission, Hearing before the House of Representatives, Committee on the Merchant Marine and Fisheries, January 26, 1928, at 2 (1928).

${ }^{56}$ Minutes, March 29, 1927, 39. A third commissioner, Orestes Caldwell, bemoaned interference as the issue "on which is based the whole problem of allocation of stations all sharing the wave lengths" [Minutes, 97]. Caldwell said the commissioners intended to found a "listeners' paradise," and their interpretation of the listener's interest was clearly the promotion of interference-free broadcasting [Hugh R. Slotten, Radio and Television Regulation (2000)].
} 
of other types of radio transmission it is going to be better at this time to make a change in the broadcasting band." 57

\section{Expanding the Broadcasting Band: A Decidedly Unpopular Proposal}

Although the proposal to expand the broadcast band became the first topic of discussion at the FRC hearings, it is not entirely clear where the proposal originated. Commissioner Bellows noted early on in the first session that "a great many of those who have written to us have very strongly urged this change."58 However, he seemed to contradict himself on this point the very next day when he announced that over 3000 letters had been analyzed so far and that on "the subject ... of widening the broadcast band, it is quite extraordinary how few letters have come into the Commission advocating a change in the broadcast band." 59

In any case, the main proposal on the table would have enlarged the existing 96channel 550-1500 kHz (545 to 200 meters) band to include 50 more channels on the 1500$2000 \mathrm{kHz}$ (200-150 meters) portion of the spectrum. ${ }^{60}$ Participants at the hearings appeared to view the expansion proposal primarily as an option for reducing interference by moving some existing stations to the new band, although they also recognized that new broadcasting spectrum would likely spur new broadcasting entrants as well. ${ }^{61}$

Opposition to this proposal was nearly universal at the hearings. In fact, the opposition was so strong and so widespread that it seemed to catch the commissioners by surprise, leading them to ask whether "there are any persons present who do advocate the increase of the broadcasting band...." 62

\footnotetext{
57 Minutes, March 29, 1927, 3. Subsequent topics taken up at the hearings included "Limitation of Power," "Reducing Frequency Separation,” "Simultaneous Broadcasting with Same Frequency,” "Chain Broadcasting,” "Division of Time," "Consolidation of Broadcasting Service," and "Limiting Number of Broadcasting Stations” [Minutes, 2]. Many of the FRC's regulations over subsequent weeks and years reflected the dominant recommendations voiced in these hearings. Even the hallmark "clear channel” system, classifying stations by power and assigning them more or less crowded wavelengths, was prefigured in plans presented during these hearings. See esp. the proposals of E. H. Felix, Minutes, 81-84, and the American Engineering Council, id. at 200-217.

${ }^{58}$ Minutes, March 29, 1927, 32.

${ }^{59}$ Minutes, March 30, 1927, 165. Unfortunately, we were unable to locate any of these letters, or the analysis that Bellows described, in either the National Archives or the Herbert Hoover Presidential Library.

60 There apparently had been some interest in expanding in the other direction, below $550 \mathrm{kHz}$ (above 545 meters), but this proposal received less serious attention at the hearings, presumably because it would have impinged on existing maritime frequencies.

${ }^{61}$ While broadcaster Ira Nelson opposed expansion because of the pro-competitive effect of new entrants upon the industry (Minutes, March 31, 1927, 284-286), broadcaster H. V. Hough saw it as the clear answer to the problem of accommodating the large number of existing stations (Minutes, March 31, 1927, 325-327), and NBC representative Alfred Goldsmith also offered it as one (rather poor) solution to the congestion problem caused by the many existing stations all attempting to broadcast (Minutes, March 29, 1927, 22-23). See infra.

${ }^{62}$ Minutes, March 29, 1927, 32.
} 
Before moving on to each of the groups that testified at the hearings, it is worth noting that our assessment is based to a very significant extent on historical records that have remained largely unexamined until now - namely, the transcripts of the FRC's first public hearings. These transcripts, which we obtained from the Herbert Hoover Presidential Library after being informed that they could not be located at the National Archives, represent the most exhaustive available record of debate and testimony on the expansion issue. A great many individuals representing the full gamut of radio interest groups made their case to the Commission over several days of hearings. Perhaps the most remarkable fact to emerge from their testimony - and the one that most starkly contrasts with the prevailing view within the literature - is that nearly all the of interest groups represented at the hearing agreed on the inadvisability of the expansion proposal. Far from standing alone on the issue, broadcasters who objected to expansion joined engineers, manufacturers, amateur operators, and listeners in opposing the plan to add new frequencies to the broadcast band.

\subsection{Radio Engineers}

The strongest arguments against expansion were generally articulated by radio engineers, who questioned whether the substantial technical challenges and difficulties associated with the proposal could be justified. Specifically, the engineers emphasized that the new wavelengths would not be conducive to reliable broadcasting; that transmissions on the additional frequencies would face harmonic interference from high-powered stations on the existing frequencies; and that new radios covering the expanded band would be difficult to design, would offer poorer performance, and would be considerably more expensive.

Professor Louis Hazeltine, inventor of the neutrodyne receiver and a member of the board of the Hazeltine Corporation, a radio manufacturer, explained in a letter to the commission that "the designing engineer well knows that to increase the frequency covered by radio receivers will either make its performance poorer at each frequency which it covers or else will make it considerably more expensive, or more likely of all, will both impair its performance and increase its cost.” He suggested that although

the present frequency band was allotted to broadcasting largely by reason of special circumstances ... it is ... just the band that the designing engineer would pick out as the most suitable.... The reason is that the natural selectivity [the ability to tune in just one station] of ordinary tuned circuits in the present frequency band is just about right to give the desired fidelity [the ability to hear broadcasts clearly] ... by covering the side bands [the $5 \mathrm{kHz}$ on either side of the broadcasting frequency] and no more.

Finally, he warned that "at higher frequencies, shorter waves, the selectivity would naturally be poorer than is necessary to secure fidelity." 63

R. H. Langley, an engineer associated with the Crosley Radio Corporation, placed particular emphasis on the problem of interference:

${ }^{63}$ Minutes, March 29, 1927, 8-9. 
In the present band of frequencies from 750 kilocycles $[\mathrm{kHz}]$ down, it is possible to receive the second harmonic of each broadcasting station on an ordinary broadcast receiver. This means that if the local station which you are anxious to avoid is at 750 kilocycles or below, he is in shadow in the upper range of your receiver, and if he is loud enough, you are quite likely to get him in two places. If the band was widened down to 150 meters [2000 $\mathrm{kHz}$ ], then 71 of the 146 channels would have this second harmonic reflection point and would be received at two points on the receiver, if you were near enough to them, and the signal were sufficiently powerful. ... That difficulty ... of the harmonics, would mean that all of the new channels would be open to that difficulty.... ${ }^{64}$

Making implicit reference to the extension of the broadcast band from 1350 to $1500 \mathrm{kHz}$ in 1924, Langley also observed that there were actually very few receivers on the market that went all the way up to the then-allowable $1500 \mathrm{kHz}$. ${ }^{65}$ "Many of the circuits now in use are extremely difficult to stabilize," he explained, "especially the upper frequency. Some of the circuits now in use ... would be impossible to stabilize at very much higher than 1500 kilocycles, and some new means would have to be provided to get a suitable amplification at the higher frequencies." Like Hazeltine, he predicted that to "build a receiver which would be as satisfactory as the better receivers are today would make it cost considerably more.”66

Dr. Alfred N. Goldsmith, Chairman of the Board of Consulting Engineers for NBC and a luminary in the field of radio engineering, began his comments by acknowledging the problem that expansion of the band was intended to solve. The existing broadcasting band (from 550 to $1500 \mathrm{kHz}$ ) provided 95 channels, ${ }^{67}$ six of which had been allotted to Canada. The remaining 89 "American channels are now called upon to accommodate more than 730 existing broadcasting stations. The congestion is, therefore, extreme and the interference correspondingly great." For this reason, expansion of the band had to be considered. "In the abstract," Goldsmith declared, "there can be no objection to the widening of the frequency bands ... provided the additional frequencies ... are suitable for broadcasting.... It

\footnotetext{
${ }^{64}$ Minutes, March 29, 1927, 14-15.

65 The October 1924 National Radio Conference recommended raising the upper broadcasting frequency from $1350 \mathrm{kHz}$ to $1500 \mathrm{kHz}$. The primary objective of this expansion was to provide a band for "all broadcasting stations which use less than 100 watts power," in order to grant "great improvement" to higher-power stations, which would then be "relatively free from local interference produced by the stations of very small power which, on the average, furnish a grade of program which is of only local and limited interest" [Recommendations for Regulation of Radio Adopted by the Third National Radio Conference (1924)]. The recommendation was apparently adopted: as late as mid 1927, the average power of a station in the 550-590 band was over 1000 watts, while in the 1460-1500 band it was only 75 watts [Commerce, Radio Stations]. Ironically, then, the proposal to expand the broadcast band - which Hazlett and others believe ran contrary to the interests of incumbent broadcasters in 1927 - may actually have been used to advance the interests of major incumbent broadcasters in 1924.

${ }^{66}$ Minutes, March 29, 1927, 16-17.

67 Although most authorities on the subject, including the Commission itself, spoke of 96 channels (six of which being reserved for Canadian stations), some - including Goldsmith - spoke of 95.
} 
must be recognized, however, that the usefulness of such frequencies for this purpose has not been demonstrated by large scale experiments up to the present time.”68

Although most of the engineers who testified on the expansion issue at the FRC hearings were affiliated with either a broadcasting company or (more commonly) a radio manufacturer, there were others present who were not so affiliated. John Dellinger, chief of the Bureau of Standards' Radio Section in 1927, had been president of the Institute of Radio Engineers (IRE) in 1925 and director from 1924-27. (He subsequently served as Chief Engineer for the FRC from 1928-29 and, in 1938, was awarded the IRE Medal of Honor.) While Dellinger did not explicitly comment on expansion at the FRC hearings, he did speak at great length about the problem of heterodyne interference, which he characterized as "probably the worst thing we have to combat in the radio broadcasting allocation today." 69

In addition, the Radio Broadcast Committee of the American Engineering Council issued a report, which was presented to the FRC at the March 30 hearing, offering a "compilation of engineering principles and facts believed to affect the duties of the Federal Radio Commission." "Among other things, the report concluded that the proposal to widen the broadcast band "is not now practicable" because such widening would impinge on "other useful radio services," would render millions of existing sets obsolete, would require more complicated and more expensive radio receivers, and would "increase the number of stations open to interference from harmonics or other broadcasting stations." "71

\subsection{Radio Manufacturers}

To a large extent, the position of radio manufacturers on the question of widening the spectrum has already been presented, since many of the engineers just quoted were affiliated with manufacturing companies and were specifically lined up to speak at the FRC hearings by the Radio Manufacturers' Association. ${ }^{72}$ In his letter to the commission, Louis Hazeltine quoted a recent resolution in which "engineers associated with the Independent Radio Manufacturers, Inc., and with the Hazeltine Corporation, assembled in conference on

\footnotetext{
${ }^{68}$ Minutes, March 29, 1927, 22-23.

${ }^{69}$ Minutes, March 30, 1927, 116. Three years later, Dellinger published an article noting that although the notion of expanding the broadcast band "has been a major issue at every national and international radio conference since 1924," these conferences had "uniformly concluded that extension of the broadcast range of frequencies is impracticable for several reasons" [John H. Dellinger, The Broadcasting Band, in Radio and its Future 293 (Martin Codel ed. 1930)].

${ }^{70}$ Minutes, March 30, 1927, 200.

${ }^{71}$ Minutes, March 30, 1927, 202-203. The committee comprised both affiliated engineers (such as Calvert Townley, assistant to the President of the Westinghouse Electric and Manufacturing Company, Alfred Goldsmith of NBC, David Sarnoff of RCA, and L.E. Whittemore of ATT) and unaffiliated engineers (such as John Dellinger of the Bureau of Standards and C. Moreau Jansky Jr., Assistant Professor of Radio Engineering at the Univesity of Minnesota). See Will Survey Radio Needs: Engineering Council Names Committee to Suggest Control Legislation, N. Y. Times, Jan 14, 1927, at 10. Note that Jansky, characterized in his obituary as a "pioneer in radio broadcasting" subsequently was "co-founder and chairman of Jansky \& Bailey, a consulting engineering company formed in 1930...” [C. Moreau Jansky Jr., 79, Pioneer in Radio Broadcast, N. Y. Times, March 27, 1975, at 28].

${ }^{72}$ Minutes, March 29, 1927, 5-6.
} 
March 17, 1927," unanimously resolved "that in the present state of the radio art, it would be against the best interests of the broadcast listening public to increase the frequency band...."73

An intriguing question - especially for students of the economic theory of regulation - is why radio manufacturers would oppose expansion of the broadcasting band in the first place, since one might assume they would stand to benefit from increased demand for new radios. By the beginning of 1927, the number of American homes with radio receivers had reached 6.5 million. Since 1922, when only 60,000 homes had radio sets, the increase in radio penetration had been about 1 to 1.5 million homes per year. ${ }^{74}$ Given this, one might think manufacturers would have found the prospect of obsolescing a large part of the existing stock to be absolutely tantalizing. But apparently they had other concerns.

One possible explanation that deserves consideration is that the manufacturers opposed widening the band because they owned a large number of radio stations, which they wanted to protect against competition. One problem here is that most manufacturers at the time had a much larger stake in radio manufacturing than in radio broadcasting, particularly since most broadcasters were still making little if any money and annual radio sales remained exceedingly large. Another problem is that the opposition to widening expressed at the hearings was voiced at least as strongly, if not more strongly, by manufacturers with no discernible connection to broadcasting, such as Jack Binns, treasurer of the Hazeltine Corporation, and L.P.F. Raycroft of the Electric Storage Battery Company. ${ }^{75}$

Indeed, Raycroft himself insisted that the reason he and his fellow manufacturers opposed widening the band was that it would harm them by harming their customers, the nation's radio listeners. "The radio broadcast listeners are by all means our customers and our customers must be satisfied," he said. ${ }^{76}$ Raycroft was speaking on behalf of the radio division of the National Electrical Manufacturers Association, the members of which, he claimed, accounted for more than three-quarters of radio production in the United States. ${ }^{77}$ The main problem, as he saw it, was that widening the band would render existing radios obsolete. And this was no small matter, since he estimated that the average radio cost about $\$ 100$ in $1927,{ }^{78}$ which was more than 10 percent of per capita GDP at the time (the equivalent of more than $\$ 4500$ today). “Gentleman,” he declared at the hearings,

I want to tell you this; when we appeared before the Congress in the strongest sort of support for the legislation [the Radio Act of 1927] which is

\footnotetext{
${ }^{73}$ Minutes, March 29, 1927, 7-8.

${ }^{74}$ O.H. Caldwell, The Radio Market, in Radio and its Future, at 206 (Martin Codel ed. 1930).

75 Neither of these corporations is listed as a station owner in the 1927 Radio Stations of the United States. Several of the radio engineers who testified at the hearings and who worked for manufacturers that also owned broadcasters were R. H. Langley of the Crosley Radio Corporation (which operated WLW) and Ray Manson of the Stromberg-Carlson Company (which operated WHAM).

${ }^{76}$ Minutes, March 29, 1927, 52.

${ }^{77}$ Minutes, March 29, 1927, 50-51.

${ }^{78}$ Minutes, March 29, 1927, 57.
} 
now made effective, and we did so as radio manufacturers trying to protect our interests and the interests of the radio broadcast listener at large, our customers, we never conceived for one moment that we would come before any established commission and ask that it take any steps which would make practically the entire number of sets in the country obsolete, either in whole or in part, and we refuse to take that position today. As radio manufacturers, we cannot afford, in accordance of our own ethics, to appear in support of that proposition. ${ }^{79}$

Whether the radio manufacturers were truly motivated by an unwillingness to anger their customers (over 1.5 million of whom had bought new sets in just the last year alone), or perhaps by some other fear or objective, is impossible to say with certainty. Patent holders may have worried that their patents would be rendered obsolete by the change. Or, alternatively, smaller producers may have worried that the giants, like RCA, would gain even greater control over the industry as a result of their superior research capabilities. In fact, there are many possible explanations. Unfortunately, we were unable to find appropriate and compelling evidence that distinguishes between them.

Still, the position of manufacturers at the hearings was clear. Langley (of the Crosley Radio Corporation) observed that if the broadcasting band were widened, it would "immediately obsolete not only the receivers which broadcast listeners have already purchased, but also the receivers which are now on the shelves in dealers' stores, and also the receivers which are now in the process of being put into production in factories of the manufacturers." ${ }^{80}$ What is more, "there would be a period of three, four or five months during which all the manufacturers would have to work under intense pressure to develop some new form of receiver that would cover the band." While he insisted that he personally was "not a bit loathe to undertake that work for myself and my group of engineers" (since it would be "a very interesting engineering problem"), he simply could "see ... no great advantage to the listening public or to the radio manufacturers in any extension of the broadcast band." $" 11$

\subsection{Amateur Radio Operators and Experimenters}

The proposal to expand the broadcast band provoked a particularly fierce response from amateur radio operators. This was mostly because the wavelengths under consideration had, for some time, been the domain of the amateurs. From the perspective of the amateur operator, commercial broadcasting from 1500 to $2000 \mathrm{kHz}$ would amount to criminal trespass on his own precious real estate.

\footnotetext{
${ }^{79}$ Minutes, March 29, 1927, 58 (emphasis added).

${ }^{80}$ Minutes, March 29, 1927, 18.

${ }^{81}$ Minutes, March 29, 1927, 18. At the conclusion of his statement, Langley noted that in making his statement he was representing the Amrad Corporation as well as the Crosely Radio Corporation.
} 
On the very first day of the hearings, Secretary K. B. Warner of the American Radio Relay League (ARRL) ${ }^{82}$ dismissed claims that amateurs were no longer interested in the $1500-2000 \mathrm{kHz}$ band, emphasizing that only this band could be used for voice communications: "This is the only amateur band in which really successful amateur telephony is possible, because all of our shorter waves [higher frequencies] are subject to technical difficulties such as audio-frequency fading which, while they do not adversely affect telegraphy, do make it extremely difficult to carry on successful telephony." ${ }^{83}$ If there were to be any significant advances made in voice transmission, he argued, it would need to take place in the $1500-2000 \mathrm{kHz}$ band.

The commissioners had good reason to take the amateurs seriously. Many radio amateurs began as military radio operators during the war, and amateur use allowed them to continue to hone their skills. Furthermore, amateurs had historically been at the forefront of radio innovation, having shown not only that frequencies above $1500 \mathrm{kHz}$ could be used, but also that they propagated to far greater range than those below. Confined to the socalled trash wave lengths, early radio amateurs took great pride in their successful transcontinental and trans-oceanic communications. ${ }^{84}$ According to the 1930 president of the ARRL, "the success of the amateur with his short waves naturally stimulated all manner of commercial aspiration." As the broadcast spectrum crowded, the ARRL feared this meant "ejecting the amateurs from some of the territory that they had done so much to pioneer." 85

Another speaker, C. Francis Jenkins, was even more adamant about what could be lost to society if amateurs were deprived of the frequencies above $1500 \mathrm{kHz}$. An inventor and amateur lab operator experimenting with the broadcast of still images (or "radiofacsimile"), Jenkins urged that "this band below 200 meters [above $1500 \mathrm{kHz}$ ] should be kept more or less virgin field for the amateurs who have no particular object other than that of developing useful applications of radio." ${ }^{86}$ He no doubt captured the attention - and the imagination - of the commissioners when he began speculating about the possibility of broadcasting moving pictures over the airwaves:

Presently, when what we call still pictures are considered fairly well launched on their useful career, we want to take up a still further development, which has been shown by experiment to be perfectly feasible with the apparatus that we have today, and that is radio vision, the ability to see on a small white screen, if you like, what is happening at a distant place. ${ }^{87}$

The one catch, he suggested, was that experiments of this sort would have to take place in precisely the same part of the spectrum that the commission was considering giving away to

\footnotetext{
82 The ARRL continues to operate to this day as the country’s premier amateur radio organization.

${ }^{83}$ Minutes, March 29, 1927, 29.

${ }^{84}$ Hiram Percy Maxim, The Radio Amateur, in Radio and its Future 149.

${ }^{85}$ Id. at 155.

${ }^{86}$ Minutes, March 29, 1927, 35.

${ }^{87}$ Minutes, March 29, 1927, p. 34.
} 
radio broadcasters: "[B]ecause we need electrical pulsations to make up radio vision, electrical pulsations of such high frequency, we rather expect that it is in the amateur band only that radio vision is possible." ${ }^{88}$

Apparently tantalized by the specter that Jenkins had conjured up, the commissioners ultimately relied heavily on the promise of experimentation in justifying their decision not to expand the broadcast band. According to the FRC's General Order no. 4, "the band between 1,500 and 2,000 kilocycles (199.9 to 149.9 meters) should, so far as may be practicable, be held open for experimental work in broadcasting and allied forms of radio service, to the end that, with the further development of the art, this band may be eventually made available for broadcasting, whether for the ear or the eye." ${ }^{\text {"9 }}$

Although radiofacsimile never took off, the FRC did make good on its promise that the frequencies near to the existing band be used for experimentation with new forms of broadcasting. Jenkins himself received the very first license for an experimental 1927 television station, W3XK, in the adjacent $2000-2100 \mathrm{kHz}$ band. ${ }^{90}$ Furthermore, throughout the 1930s, several high-fidelity AM stations operated with experimental licenses between 1500 and $1600 \mathrm{kHz}$, each occupying $20 \mathrm{kHz}$ of bandwidth. ${ }^{91}$ In 1936, W2XR famously received an experimental license for high-fidelity stereo broadcasting. ${ }^{92}$ When regulators officially expanded the broadcasting spectrum to $1600 \mathrm{kHz}$ in 1941, W2XR began operation as WQXR, which continues to operate to this day (on FM) as one of New York's most popular classical stations.

\subsection{Radio Listeners}

As the commissioners themselves repeatedly noted, listeners were the commission's most important constituents. To quote Commissioner Bellows, "[I]t is the radio listener we must consider above everybody else." 93 The problem, of course, is that listeners were not as well organized as most of the other interests. Consequently, listener representation at the FRC hearings was not very strong. But neither was it missing altogether.

According to those who claimed to represent them, listeners preferred a smaller number of good stations to a larger number of poor and overlapping ones. ${ }^{94}$ Francis St.

\footnotetext{
${ }^{88}$ Minutes, March 29, 1927, 34.

${ }^{89}$ FRC 1927 Annual Report, 13.

${ }^{90}$ R. W. Burns, British Television: The Formative Years 116-17 (1986).

${ }^{91}$ Sterling and Kittross, Stay Tuned, 109.

92 The number after the "W" indicates an amateur or experimental license.

${ }^{93}$ Minutes, March 29, 1927, 40.

${ }^{94}$ In addition to the statements at the hearings cited below, see also Radio Freedom of Speech Impossible, 11 Radio Broadcast 138-139 (April 1927), reporting in general terms on the results of their questionnaire to readers (listeners). For example, the magazine's editors declare, "We are in favor of eliminating a great number of small stations so that we may have more great stations. This is our stand because it is sound common sense and because it is the expressed wish of a majority of our readers” (139).
} 
Austell, president of the Iowa Radio Listeners' League, exclaimed on the second day of the hearings:

The broadcaster at the present time has brought about a great deal of confusion for the simple reason that there are so many stations on the air that the ordinary listener, with a $\$ 150$ set is practically incompetent to get anything. ...

Damn it, I don't want to listen to a lot of rotten stuff over the air, but I want to listen to something good, to a good concert, for instance, and feel that the broadcaster is a friend of mine, and that he is not an enemy of the other broadcasters. ...

... We do not want 733, or whatever the number is, on the air; we want to get good broadcasting.... ${ }^{95}$

L. P. F. Raycroft, a manufacturer, agreed: "I could say $90 \%$ easily, of all the broadcast listeners with whom I have spoken, have stated in regard to the question as to the number of broadcast stations that should be allowed upon the air, that they did not care how few they were if they could have such and such a station left, and in some localities it was WJZ, and in others WEAF, and in others other stations." Raycroft added that the days of listeners trying to hear every last station - "and add those scalps to their belt" - were basically gone. What the listeners had come to want "was good substantial broadcasting of a quality character, and ... they are willing to hook up pretty well to one, or a small number of large stations, or nearby stations to satisfy that desire on their part."96

Interestingly, Raycroft also reported on some correspondence he had had with the Broadcast Listeners' Association of Minneapolis - specifically regarding one of the association's resolutions that seemed to favor broadening of the broadcast band. When he wrote to the association on "January $7^{\text {th }}$ and called their attention to some of the difficulties involved in their suggestion on the basis of good engineering advice," their response was telling:

You will note from a careful reading [of the resolution] that we do not urge this change but that we suggested that Congress encourage a study of the matter by competent engineers.... We are not sure that this would be a good thing for radio but hold our minds open for competent advice in these matters so the real purpose of that recommendation was to accomplish the result that has been brought about, namely, an intelligent discussion both for and against the proposal ... and therefore, we are not urging the change unless it should be found entirely practicable and an advantage to the advancement of radio. ${ }^{97}$

\footnotetext{
${ }^{95}$ Minutes, March 30, 1927, 144-146.

${ }^{96}$ Minutes, March 29, 1927, 57.

${ }^{97}$ Quoted in Minutes, March 29, 1927, 55-56.
} 
Willing to entertain widening of the band so long as it was "entirely practicable," the Broadcast Listeners' Association of Minneapolis appears to have taken a position remarkably similar to that of Goldsmith at NBC.

On the final day of the hearings, P. A. Green of the United States Radio Society, a national radio listeners' organization, reinforced the notion that the costs of widening the band likely outweighed the benefits. "Although the opinions of the radio listeners of the United States have not been presented on this particular subject," he remarked, "I am of the opinion that to widen the band at this time would possibly work a hardship on the present users of radio receiving sets. Therefore the society recommends that the broadcasting stations be assigned frequencies within the now existing bands."98 Apparently, the threat of having their radios rendered obsolete - or, at least, no longer complete - was a real concern to listeners. ${ }^{99}$

At least one prominent radio enthusiasts and listeners' magazine, moreover, staunchly opposed widening the band, both in contemporary articles and through its representative who spoke at the hearings, offering further evidence of where listeners stood on this issue. The magazine was none other than Radio Broadcast. ${ }^{100}$ Its editors certainly minced no words, urging the commission in its articles "to dispose of such dangerous propositions as the pressure to extend the broadcast band downward, brought by shortsighted would-be broadcasters and selfish set manufacturers, seeking to create an artificial market for short-wave receivers...."101 Like some of the other listeners' representatives already quoted, the magazine subscribed to the notion that less was more, as far as radio listeners were concerned, since interference compromised reception: "The principle must be recognized that the fewer broadcasting stations there are on the air, the more stations the listener can enjoy." 102 Expansion of the broadcasting band was decidedly not the answer.

\subsection{Radio Broadcasters}

In some ways, the position of the broadcasters on the proposal to widen the band paralleled that of the manufacturers. In fact, the very same person who lined up speakers for the Radio Manufactures' Association also lined up speakers for the National Association of Broadcasters. Frank D. Scott, a former congressman from Michigan, represented both

\footnotetext{
${ }^{98}$ Minutes, April 1, 1927, p. 352.

99 Interestingly, another major concern, according to Green, related to direct advertising (which today would simply be called "advertising," as opposed to indirect advertising, or sponsorship). "The United States Radio Society has received many communications of protest against the use of the air as a means of direct advertising. The opposition to this type of broadcasting has been so strong that the society has recently started a campaign against this evil...” [Minutes, April 1, 1927, 354]. Significantly, Francis St. Austell of the Iowa Radio Listeners' League, quoted above, took the same position about a year later. According to the New York Times, Austell's Listener's League was circulating petitions to make the practice of direct selling over radio illegal. "The petitions," noted the Times, "brand direct selling as unfair competition and a menace to the retail business structure of the country” [Selling by Radio Opposed, N. Y. Times, Feb 1, 1928, 20].

${ }^{100}$ See discussion supra on the mischaracterization of Radio Broadcast as a trade journal.

${ }^{101}$ Welcome to the Radio Commission, Radio Broadcast, at 555 (April 1927).

102 Welcome to the Radio Commission, Radio Broadcast, at 555 (April 1927).
} 
organizations at the hearings and put together a combined slate of speakers, who spoke at the outset of the first session. ${ }^{103}$

Without question, one can find statements of naked self-interest on the part of some broadcasters, just as one might expect from incumbents trying to protect their competitive positions. Ira Nelson of WAAM in Newark, for example, announced on the third day of hearings that the central question was: "Who shall broadcast?"104 In answering this question, he cautioned that "[i]t should not be our attitude to foster the inauguration of many stations, realizing that most of them will find it well-nigh impossible to earn three squares a day." New entrants were continually coming into broadcasting, he lamented, despite "a great many warnings of deep water ahead to our new brethren.... The increased number of broadcasting stations has worked a great hardship upon already established commercial organization[s] who have for years been building up audiences and services so that they might have something to sell...."105 What was necessary, he believed, was not for the commission "to open any more broadcasting channels" but for it to weed out weak stations, based on "their respective incomes in payment of their services, and the degree of satisfaction they have produced for their clients." 106 Ultimately, the commission would have to decide "who shall stay, taking into consideration only one class. Commercial stations who have a previous record of faithful service, should be retained.”107

In spite of the comments of Nelson and others, what is most striking about the commercial broadcasters is that they were - if anything - less unified and less vehement in their opposition to the proposal for widening the broadcast band than were most other groups represented at the hearings. In fact, at least as many broadcasters spoke for the proposal as spoke against it. ${ }^{108}$ Ira Nelson, it turns out, did not represent all of his brethren in the broadcasting industry.

As we have seen (in the section on engineers), Alfred Goldsmith expressed ambivalence about the proposal to widen the band, even though he was Chairman of the Board of Consulting Engineers of NBC, which was the dominant radio network at the time and whose parent companies owned ten of the country's largest and oldest broadcasting stations. In fact, when Goldsmith finally summarized the position of NBC on the issue, it fell somewhere between weak support and weak opposition. "The ... National Broadcasting Company," he maintained, "is not opposed to widening the wave band whenever it is

\footnotetext{
103 Minutes, March 29, 1927, 5, 6-25. The lineup that Scott put together included Jack Binns of the Hazeltine Corporation (who also read a letter from Louis Hazeltine), R. H. Langley of the Crosley Radio Corporation, F. A. Kolster of the Federal Telegraph Company, and Arthur Goldsmith of NBC.

${ }^{104}$ Minutes, March 31, 1927, 281.

105 Minutes, March 31, 1927, 284-285.

${ }^{106}$ Minutes, March 31, 1927, 284, 285-286.

${ }^{107}$ Minutes, March 31, 1927, 286

${ }^{108}$ For opposition from commercial broadcasters to the proposal to expand the broadcast band, see testimony of A. H. Grebe, Ray H. Manson, and Ira N. Nelson (Minutes). For support from commercial broadcasters for the proposal, see testimony of H. V. Hough, John S. Cohen, and Landen Kay (Minutes).
} 
demonstrated to be technically feasible, and when this could be done without interference with other established radio services." ${ }^{109}$

Even more remarkable were the comments of another broadcaster, H. V. Hough of WBAP in Texas, who tried - on the third day of the FRC hearings - to resurrect the proposal for widening the band, which already appeared dead by the end of the first day due to lack of support. Hough had been operating WBAP for five years, and by 1927 was licensed for the very desirable $600 \mathrm{kHz}$ frequency and a substantial 1500 watts of power. ${ }^{110}$ By almost any definition, he was an incumbent broadcaster. Yet after sitting through the hearings and listening to attacks on one proposal after another for dealing with the interference problem, he began to think that the original proposal to widen the band might not be so bad after all:

You are hunting a solution of a problem, and I have been sitting here two or three days getting hopelessly confused all the time. ...

We have had quite a bit of discussion, and what we want to do, I believe, is to eliminate stations or eliminate interference, one or the other. One goes with the other. It just occurs to me that when we got up on our feet and told the Commission that we did not think it was a good idea to open up those lower wave bands we were traveling around in a pasture that was a good deal greener than we thought it was. ...

Some folks say that it would not be very profitable down there. I certainly would like to have a wave band for myself down about 200 meters, and in two years from now it would be as important as any other place. When they moved us from 360 to 400 they said that nobody would listen, and then later on they moved us again, and the same thing was said. It would be a sporting proposition for a man to go down there and get something that the other fellow has not got, and then the next day the next man would be getting it, too, because each man wishes to be as well posted as his neighbor.

We have looked around in these pastures and we are right back in a circle. The proposition you submitted in reference to opening up the lower wave bands may be, after all, the solution, and we have not been able to locate it. ${ }^{111}$

Here was a "sporting proposition" indeed - coming from an incumbent broadcaster - for some new competition in the outer reaches of an expanded band!

Ironically, it was not a commercial broadcaster but rather a non-profit broadcaster who articulated perhaps the clearest and most unequivocal statement of opposition to expansion on the third day of the hearings. When another speaker proposed that educational stations should be allocated the $1500-1600 \mathrm{kHz}$ frequencies, for which special educational

\footnotetext{
${ }^{109}$ Minutes, March 29, 1927, 25.

${ }^{110}$ Department of Commerce, Commercial and Government Radio Stations of the United States, at 77 (1927).

${ }^{111}$ Minutes, March 31, 1927, 325-327.
} 
band radios could be produced, C. A. Culver, president of the Association of College and University Broadcasting Stations, responded resolutely. University broadcasters, Culver insisted, sought to provide more general cultural services in addition to straightforward education, and they would find this new fragment of spectrum "practically prohibitive, because the listeners would have to have special receiving sets, and that would practically inhibit the service that they want to give in those regions." Repeating his key point as he concluded his remarks, he again warned that "to take a band at this extreme end down below all the other broadcasting would be practically prohibitive and would cut [the stations that were moved there] out from the service they are certainly rendering now.”112

Non-profits did not want to risk being reassigned to a lower wave band (higher frequency), which would be of lower quality and would force their listeners to purchase new and potentially more expensive equipment in order to hear their programs. In fact, it may be that Hough of WBAP was willing to entertain the opening of new wavelengths to broadcasting precisely because he knew there was little or no risk of his five-year-old commercial station ending up there.

Overall, by our count, the broadcasters who spoke at the hearings divided about evenly between support and opposition. H.V. Hough of WBAP ended up concluding it was probably the best way of addressing the interference problem; at least two other broadcasters weakly supported the idea; and Alfred Goldsmith of NBC expressed ambivalence. Three other broadcasters (including C. A. Culver) opposed the expansion proposal at the hearings, two strongly and one weakly.

There is no way to know for sure whether the broadcasters who testified were representative of broadcasters more generally and, if so, why they were not more unified in their opposition to the expansion proposal. Still, a few possible explanations for their lack of unity on the issue are worth considering. Since it was widely believed among radio engineers at the time that the frequencies above $1500 \mathrm{kHz}$ were inferior as far as broadcasting was concerned, incumbent broadcasters with the requisite technical expertise may not have felt particularly threatened by the prospect of new competitors broadcasting on those upper frequencies. In fact, expansion could well have been regarded - as it was when the edge of the band was shifted from 1350 to $1500 \mathrm{kHz}$ in $1924^{113}$ - as a way of clearing out the good frequencies, by moving the weak (some would say, bothersome) stations off to the periphery. From NBC's perspective, moreover, additional room for more broadcasters was not necessarily a net negative, since the added stations could create additional demand both for one of its primary products (radio programs sold to affiliate stations) and for one of the primary products of its parent company (radio receivers). Finally, since radio advertising remained rather primitive by today's standards and since relatively few stations were making much money, the rents that incumbents might have sought to protect may not have appeared nearly as large or as promising back then as they would to us now, biased as we are by today's far more lucrative radio environment. ${ }^{114}$

\footnotetext{
112 Minutes, March 31, 1927, 277.

${ }^{113}$ Recommendations for Regulation of Radio Adopted by the Third National Radio Conference (1924).

${ }^{114}$ Another possibility is that it was all an act. Perhaps, behind the scenes, all of the broadcasters fiercely opposed expansion and were conspiring with the commissioners to kill the proposal, but did their best to hide
} 


\section{A Search for Additional Evidence of Regulatory Rents}

In reviewing the history of the FRC decision, we also searched for additional confirming evidence of the capture interpretation - especially for any indication that the federal commissioners derived improper personal benefits from those they were regulating. But we were able to find little evidence of this kind.

Students of political economy sometimes point to turnover between public and private practice in an industry - the so-called revolving door - as evidence of rent-seeking. ${ }^{115}$ Those moving from industry to government may seek to control regulation to benefit their friends and their investments, while those remaining in industry may reward regulators with high-paying jobs for their faithful service.

In creating the FRC, President Coolidge appointed five members: Henry A. Bellows, John F. Dillon, Eugene O. Sykes, Orestes H. Caldwell, and William H. G. Bullard. Of the five, Commissioner Bellows did enter public service after managing a commercial station. Of the four remaining commissioners, two were government radio authorities, one was a magazine editor, and another was a Justice of the Mississippi Supreme Court. ${ }^{116}$ If Bellows were indeed a broadcasting insider, then broadcasters chose rather poorly, since he left the commission on October 8, 1927, less than seven months after the commission was formed. ${ }^{117}$ His reason for leaving was not framed as a whim or an act of conscience, but a financial reality. Congress had failed to approve the Commissioners' salaries, and Bellows did not have the resources to wait for back pay. In his own words, he was "starved out,"118 forced to return to his old employer, WCCO.

Thus only one commissioner entered from broadcasting, and only one, the same one, returned there. Dillon and Bullard's deaths seven and eight months into their terms complicate this conclusion; ${ }^{119}$ but Caldwell returned to his magazine post by $1930,{ }^{120}$ and

this from the public by taking a more moderate position at the hearings. While this explanation is possible, we were unable to find any evidence in support of it.

${ }^{115}$ See George J. Stigler, The Theory of Economic Regulation, 2 Bell J. Econ. \& Management Science 13.

${ }^{116}$ Bellows managed the station WCCO before being appointed to the FRC (Hearing Before the Committee on Interstate Commerce, United States Senate, on the Confirmation of Federal Radio Commissioners 79, January 1, 1928). Bullard was the Navy admiral who engineered the formation of RCA. While Bullard was officially the government representative on the RCA board, the government connection to RCA was more likely rooted in xenophobia than in capture, stemming from the post-war concern that the leading manufacturer of radio equipment was a British company (Bensman, Beginning of Broadcast Regulation, 218-19). Bullard, by the way, was not present at the hearings since he was in transit from China (Radio Board Calls Public Hearings, N. Y. Times, March 16, 1927, p. 27). Caldwell was the editor of McGraw's Radio Retailing before his appointment, and provided evidence denying rumors that McGraw had ties to General Electric during his reappointment (1928 Hearings on the Confirmation of Commissioners, 155). Dillon was Commerce's radio inspector for San Francisco (11 Popular Radio 413, April 1927). Sykes was a Mississippi judge before joining and then chairing the Commission. (Id.)

${ }^{117}$ Gleason Archer, Big Business and Radio 301 (1939).

${ }^{118}$ Hearing Before the Committee on Interstate Commerce, United States Senate, on the Confirmation of Federal Radio Commissioners 101 (January 1, 1928).

${ }^{119}$ Dillon died on October 8, 1927, and Bullard died on November 24, 1927, having spent much of his tenure in China. Archer, Big Business, at 307, and Erik Barnouw, A History of Broadcasting in the United States vol. 1 
Sykes remained a member of the FRC and then the FCC for 12 years before retiring to legal private practice. ${ }^{121}$ Even Bellows's immediate departure was merely to his former position in broadcasting. By 1930, Bellows had accepted a vice presidency at CBS. ${ }^{122}$ CBS, however, had only been broadcasting for a few weeks when Bellows left the Commission, ${ }^{123}$ and it still had little credibility in the industry and remained financially tenuous at the end of 1927. ${ }^{124}$ If one had tried to predict which of the two networks during Bellows's tenure would seek favors from a commissioner or reward a commissioner's services with an executive position, NBC would have been the obvious candidate. Since Bellows did not end up at NBC, but actually found high-level work at its primary competitor, one would be hardpressed to call his career path obvious evidence of rent seeking.

Another standard argument in the literature is that legislators, themselves beholden to powerful interests, may tie regulators' reappointments to satisfactory treatment of the regulated. ${ }^{125}$ Here, in contrast to the prior argument, capture is suggested when regulators have long, rather than short, tenures in government. While some scholars have alleged that "uncertainty of tenure made the Commissioners timid rather than aggressive," 126 the evidence that commissioners might have been willing to trade favors for extended tenure is not strong. We cannot assess the reappointment futures of Dillon and Bullard because of their early deaths. Of the remaining commissioners, only Sykes and Caldwell reached the annual reappointment stage. Of those two, Sykes, whose tenure lasted 12 years, was the only one even to stay as long as what would become one full 5-year term under the permanent FCC.

Although there is relatively little evidence to suggest suspicious career paths on the part of those who made the spectrum decision, one might still wonder whether the commissioners received other sorts of benefits from those they were regulating in return for their cooperation. Initial suspicions are raised by two letters, one in 1932 from Commissioner Henry LaFount (who was not involved in the spectrum decision) and another in 1933 from Sykes (who was involved in the spectrum decision), both of whom asked highlevel NBC employees to consider their acquaintances for positions at the network. ${ }^{127}$ But inspection of the only relevant personnel records that were available to us, from 1937 and 1942, offers no evidence that NBC had placed either one of the recommended individuals in any significant position in the corporation during those years. ${ }^{128}$

\footnotetext{
211 (1966).

${ }^{120}$ Caldwell, The Radio Market, 203.

${ }^{121}$ http://members.aol.com/jeff1070/70.html, citing Broadcasting magazine 11/2/70.

${ }^{122}$ Who Was Who in America 81 (Chicago: Marquis, 1943).

123 The network’s first broadcast was on September 19, 1927. Archer, Big Business, 309.

${ }^{124} \mathrm{Id}$. at 317.

${ }^{125}$ For this charge specific to broadcasting, see Krotoszynski, The Inevitable Wasteland.

${ }^{126}$ Marver H. Bernstein, Regulating Business By Independent Commission 86 (Princeton: Princeton UP, 1955).

${ }^{127}$ Letter from Harold A. LaFount to George F. McClelland, May 30, 1932, Box 9, Folder 51, NBC Archives at Wisconsin. Letter from Eugene O. Sykes to Mervin H. Aylesworth, February 4, 1933, Box 17, Folder 34, NBC Archives at Wisconsin.

128 The job-seekers in question were Douglas A. Nowell and Horace R. Sisson. Janet W. McKee of the Library
} 
Of course, it is possible that the commissioners did receive inappropriate payments from those they were regulating, but that these payments have remained invisible because they were so well hidden at the time. All we can say is that we were unable to find any indication of such payments in the available historical records.

\section{Conclusion}

This paper has examined the proposition that, in refusing to expand the broadcast band in 1927, the FRC was responding to the appeals of incumbent broadcasters to advance their own special interest at the expense of the public interest - that this FRC decision was, in short, captured by the broadcasters. Prior studies have highlighted evidence consistent with this proposition: namely, the opposition of incumbent broadcasters to the expansion proposal. However, upon further review of the record, we found little in the way of additional confirming evidence. We also found powerful disconfirming evidence, which we believe outweighs the available supporting evidence in this case.

Most notably, we found that every major interest group - not just broadcasters opposed the expansion proposal. This is significant because it suggests that the FRC commissioners had no reason to believe that maintaining the existing band would violate the public interest in the service of any particular special interest. It also raises the question of why incumbent broadcasters would have needed to expend resources to "capture" a decision that, given the broad agreement of other interests, was nearly a forgone conclusion in any case.

We also were surprised to discover that the broadcasters who testified at the FRC hearings were themselves divided on the issue, with some opposing expansion and others apparently willing to support it. Admittedly, only a small number of broadcasters testified at the hearings, and there is no reason to believe that they necessarily constituted a representative sample. Yet until additional documents shedding light on the broadcaster position are uncovered, this is the best indication we have. (Recall that prior "evidence" of intense - and presumably unified - broadcaster opposition to the expansion proposal was mistakenly based on quotes from a radio listeners' journal, rather than a broadcasters' journal. See appendix.)

Finally, the historical record suggests that in early 1927, there was still little agreement whether radio broadcasting would ever be profitable. Thus, it seems likely that the rents that could have accrued from limiting entry might have appeared less impressive (and perhaps far less impressive) to broadcasters at the time - i.e., prospectively - than they

of Congress examined three documents in the Recorded Sound Reference Center's NBC archives, "Departmental lists for information of secretaries” from September 11, 1937, “Artist Services and Sales Department” from February 5, 1937, and “NBC New York Personnel” from March 1, 1942. These documents list higher-level personnel (i.e., "managers, assistant managers, chief clerks, talent scouts, supervisors, assistant supervisors, and evening supervisors”) in most of NBC's departments. McKee was not able to find any reference to either Nowell or Sisson in any of the records, as stated in an e-mail received March 3, 2004. Naturally, it is possible that both men had left their positions before the lists were compiled. Unfortunately, based on the records available, we are unable to rule out this possibility. 
do retrospectively today. While we do not doubt that incumbent broadcasters ultimately may have benefited from the FRC's decision not to expand the band, we simply suggest that the broadcasters themselves may not have fully anticipated the potential gains at the time.

Of course, none of these findings contradict the economic theory of regulation itself, since we would expect, based on the theory, that a regulatory proposal opposed by all major interest groups would ultimately be rejected by regulators. The evidence presented here is inconsistent only with a capture interpretation of the episode. This is significant, however, because it means that we cannot use the episode to discriminate in favor of the economic theory of regulation on the one hand as compared to a public-interest interpretation on the other.

For a case to contradict the economic theory of regulation outright, it would have to involve the converse of capture. As Stigler himself once suggested, "the theory would be contradicted if, for a given regulatory policy, we found the group with larger benefits and lower costs of political action being dominated by another group with lesser benefits and higher cost of political action."129 Students of law and economics, as good scientists, should look hard for examples of this sort - precisely because the theory predicts that “[t]emporary accidents aside, such cases simply will not arise...."130

Medicare's enactment in 1965 might conceivably constitute such a case, since the most powerful and well-organized interest group involved, the American Medical Association (which represented individuals with arguably the most at stake - physicians), failed in its very determined and well-funded effort to stop the legislation. ${ }^{131}$ It has also been suggested that the passage of anti-gouging laws may contradict a capture interpretation: “The affected firms lose money, and the 'winners' (namely the consumers that end up paying lower prices) are quite scattered. Indeed, it is difficult to know [in advance] which consumer will win by paying a low price and which consumer will lose by being rationed."132

Further historical research would naturally be required to determine if either of these cases, or if other historical cases, are consistent or inconsistent with the economic theory of regulation. But this is precisely the point. Further (and finer grained) historical research is needed if we wish to test the economic theory of regulation and enhance our understanding of the conditions under which it does (and does not) apply. Quick-and-dirty history is not only not sufficient, it is also potentially dangerous since it may lead us to false conclusions and provide false confidence in our priors.

It is certainly reasonable, as George Stigler suggested more than thirty years ago, to derive historical inferences from a compelling theory. But history should also be used as an

\footnotetext{
${ }^{129}$ Stigler, Supplementary Note, p. 140.

${ }^{130}$ Stigler, Supplementary Note, p. 140.

${ }^{131}$ See David Moss and Mary Oey, "The Paranoid Style in the Study of American Politics," unpublished draft paper, January 2008.

132 Julio J. Rotemberg, "Behavior Aspects of Price Setting, and Their Policy Implications," unpublished draft paper, July 19, 2007, p. 25.
} 
independent test of theory; and this must involve more than merely a search for confirming evidence (which, by itself, represents the historical equivalent of data mining). What might be called history-by-inference is never a legitimate test. Perusing the historical record for evidence that seems to support a favorite theory may provide some emotional comfort, but it is decidedly not the stuff of good science. Rather, good science requires that we search vigorously for disconfirming evidence as well - the goal being always to challenge the prevailing theory, to find its limits, to move beyond it, and never simply to protect it for its own sake. 


\section{Appendix: Reassessing a Critical Source (Radio Broadcast)}

The standard interpretation of the spectrum-expansion episode, which alleges capture by radio broadcasters, rests to a significant extent on evidence drawn from the "trade journal” Radio Broadcast. ${ }^{133}$ Close inspection of the publication, however, makes clear that it was not a broadcasters' trade journal. Rather, as other students of radio history have pointed out, it was "a general-interest magazine for radio enthusiasts." 134

Because this determination regarding Radio Broadcast is of such significance in assessing the FRC's expansion decision in 1927, we did not rely solely on interpretations in the literature, but also thoroughly investigated the question ourselves, on the basis of primary documents. In our view, the evidence that Radio Broadcast was aimed at listeners and radio enthusiasts, not incumbent broadcasters, is simply overwhelming.

We began with an examination of the inset advertisements, which typically suggest the type of people that advertisers believe read a magazine. If Radio Broadcast were a trade journal for broadcasters, one might expect announcements of broadcaster conventions, or perhaps promotions for microphones or transmitter components. Instead, most of the advertisements are for radio receivers and batteries. ${ }^{135}$ One of the more colorful spots announced the winner of a "Universal Reception Contest" who was able to receive 120 stations on his set, ${ }^{136}$ and another offered readers the opportunity to "earn $\$ 50$ to $\$ 250$ a week in RADIO," under the tutelage of "Master Radio Engineers." 137 The advertisements indicate a presumed readership of audiophiles with long-distance receivers, not broadcasters. Interestingly, when the magazine's publisher, Doubleday, Page \& Co., advertised Radio Broadcast in the New York Times, it promoted it (beside World's Work, Country Life, and Garden Magazine) as the magazine that "covers entertainingly and authoritatively every conceivable radio topic from the simplest to the most advanced." "138

Technical articles constitute the majority of Radio Broadcast. Again, if this were a broadcasting trade publication, one might find suggestions for improving broadcasting range, or reviews of new broadcasting equipment, or simply technical articles that discuss broadcasting to any extent whatsoever. Instead, these articles are consistently aimed at those building or modifying receivers. The March 1926 issue included the articles "Shall I Buy a Factory-Built Receiver," "Will the New Type of Condenser Improve My Set," "The RADIO BROADCAST Local Receiver," "The \$500 Short-Wave Receiver Contest," “Trickle

\footnotetext{
${ }^{133}$ Hazlett, Rationality, 154. Hazlett characterized Radio Broadcast as a "trade journal” in a section entitled "The Agenda of the Radio Broadcasting Interests."

${ }^{134}$ Huseyin Leblebici et al., Institutional Change and the Transformation of Interorganizational Fields: An Organizational History of the U.S. Radio Broadcasting Industry, 36 Administrative Science Quarterly 333 (September 1991).

${ }^{135}$ In the May 1926 issue of Radio Broadcast, there were 10 advertisements for radio set batteries, three for pre-built sets, and one for volume controls, out of 18 advertisements total.

${ }^{136}$ Id .at 15.

${ }^{137}$ Id. at 74 .

${ }^{138}$ See e.g. Display Ad no. 60, N. Y. Times, Sept 9, 1923, at BR32. See also Display Ad no. 53, N.Y. Times, Oct 18, 1925, at BR13.
} 
Chargers for Your A Battery," and "Testing and Operating the 'Aristocat,"” a new receiver. ${ }^{139}$ Additionally, a section "devoted to Solving the Problems of our Readers," answers questions like, "My receiver tunes broadly, how may I correct this?" and "I am bothered with a persistent singing noise in my receiver." 140

The only other major section of Radio Broadcast is "The March of Radio: News and Interpretation of Current Radio Events." Far from being the steadfast voice of "radio men," this section is at times vociferously pro-listener and anti-industry. In the article "What Does the Listener Want? Let Him Speak," the staff writes: "Gentlemen of the Radio Commission, let but one voice rule you! The voice of the broadcast listener! Give him fair, efficient, and equitable service! Remember, not one of those who seek to broadcast has anything but a selfish purpose, however disguised, in seeking a place in the ether!"141 This same article urges listener coordination with all the fervor of a labor organizer: "The lack of organization of broadcast listeners is a menace to their interests, a condition which would be quickly alleviated by the formation of a truly national listener organization." ${ }^{142}$ Another article proposes a plan for consolidating local stations under more powerful transmitters, so that "the monopoly of good broadcasting now held by the chain system [networks] would at last be faced with real and sorely needed competition."143 In short, "The March of Radio" sometimes assumed an anti-broadcaster perspective, including during the period of the FRC's founding. Unfortunately, it is from this section that Hazlett pulled his most damning quotes detailing the "agenda of the radio broadcasting interests.",144

As Hazlett notes, Radio Broadcast did contain a monthly feature entitled "As the Broadcaster Sees It,” authored by Carl Dreher. But while the column consistently sounded the broadcaster's self-interested voice, its title alone suggests that the way the broadcaster saw it was not necessarily the way the rest of the magazine - contributors or readership saw it. ${ }^{145}$

In 1926, the magazine provided a brief statistical survey of its own readership, entitled "Meet Mr. Average Radio Enthusiast." According to the magazine, more than 2000 readers were surveyed by mail (out of a total readership of approximately 8700), and more than 700 responded. Of the respondents, 39.2 percent were involved in the "radio business

\footnotetext{
${ }^{139} \mathrm{Id}$. at 16.

${ }^{140}$ Id. at 70 .

${ }^{141}$ What Does the Listener Want? Let Him Speak, 10 Radio Broadcast 15 (May 1927) [emphasis added].

142 Id. at 18 .

${ }^{143}$ Deliver us from Excess Broadcasting Stations. 10 Radio Broadcast 556 (April 1927).

${ }^{144}$ Hazlett, Rationality, p. 152.

145 In characterizing the broadcasters' position on the expansion issue, Hazlett did not cite this section of the magazine - the only section that did in fact present the broadcasters' perspective. See esp. Rationality, 154-155. Hazlett did cite passages from the "As the Broadcaster Sees It" section in another context namely, as evidence that incumbent broadcasters opposed time-sharing (the existing strategy of licensing the same wavelength to two or more stations for use at different times of the day). See Hazlett, Rationality, 156, 173; Carl Dreher, A New Plan to Regulate Broadcasting, Radio Broadcast 59 (Nov. 1926); Carl Dreher, What Constitutes Fair Dealing in Radio Matters?, Radio Broadcast 60 (May 1926).
} 
or allied industries," including "electrical engineers, mechanical engineers, telephone engineers, electricians, scientists and research engineers, as well as radio engineers, jobbers, dealers, and manufacturers." Another 12.4 percent were skilled workers, such as "draftsmen, carpenters, engravers, expert mechanics and the like.” Independent merchants (including "druggists, jewelers, bakers, opticians, contractors and realtors”) comprised 11.9 percent of respondents. A group labeled "professional men," which included "[d]entists, surgeons, librarians, lawyers, writers, ministers, architects, and a score of other learned professions," came in at 11.8 percent. Executives ("the patricians of industry and commerce-bankers, manufacturers, railroad officials, exporters, and importers”) comprised another 11.5 percent. Office workers (i.e., "clerks, accountants, salesmen, agents, customs inspectors") accounted for 10.2 percent of respondents. The magazine reported that the remaining 7.8 percent "were divided among students (5 per cent.), sailors, army and navy officers, coal heavers (a total of one), housewives, and miscellaneous other defenders of the home." Throughout the article, the typical reader is referred to as "Mr. Average Radio Enthusiast" and "Mr. Average Listener," hardly the way the typical reader of a broadcasters' trade journal would be characterized. ${ }^{146}$

By May 1929, two years after the founding of the Radio Commission, Radio Broadcast had indeed become a trade journal - but one for radio retailers and repairmen, rather than broadcasters. ${ }^{147}$ Whereas in October of 1926 the magazine referred to its typical reader as "Mr. Average Listener," in the May 1929 issue it wrote that surveys "would indicate that at least $84 \%$ of our subscribers are professionally connected with the industry and a very high percentage of them are dealers." ${ }^{148}$ Out of 33 advertisements, none targeted battery-seeking home tinkerers. Instead, 22 were for radio replacement parts, primarily vacuum tubes, largely directed at repairmen: one radio "diagnometer" noted its troubleshooting utility for "radio service and selling," 149 and another ad was titled, simply, "Radio Servicemen." 150 There were only two advertisements for pre-built sets, yet one

\footnotetext{
${ }^{146}$ Kingsley Welles, Meet Mr. Average Radio Enthusiast, 9 Radio Broadcast 531 (October 1926).

147 This development apparently surprised the magazine's editors. See Among Other Things, 14 Radio Broadcast 82 (December 1928) ("With this issue, we start the promised department for radio service men. The service man is a most important element in the radio structure but for some reason or another he has been inarticulate. We know that a great many readers of RADIO BROADCAST are doing service work, either on whole- or part-time and we hope that those who are doing this work will write us.”); Among Other Things, 14 Radio Broadcast 154 (January 1929) ("No new feature we have added to RADIO BROADCAST in the six years of its history has created anything like the favorable response that the special pages for the radio service man have produced."); Among Other Things, 14 Radio Broadcast 224 (February 1929) ("Radio dealers and servicemen are writing in great numbers with the most enthusiastic praise for the sections of this magazine written especially to help them. Our plans for the coming months include many articles which no serviceman or dealer can afford to miss.”); Among Other Things, 14 Radio Broadcast 288 (March 1929) ("We call especial attention to the new section of RADIO BROADCAST, 'In the Radio Marketplace.' This new news section of the magazine will, as our plans develop, become increasingly useful to every reader who is in the radio industry.”); Among Other Things, 14 Radio Broadcast 364 (April 1929) (“The welcome given this feature ['In the Radio Marketplace'] has been most encouraging”).

${ }^{148}$ Are You a Dealer?, 15 Radio Broadcast 57 (May 1929). By the June issue its cover included the subtitle "Published for the Radio Industry."

${ }^{149}$ Supreme Radio Diagnometer, 15 Radio Broadcast 1.

${ }^{150}$ Radio Servicemen, 15 Radio Broadcast 56.
} 
other manufacturer advertised "tube branding machines" that would allow any small operator to put its trademark on vacuum tubes. ${ }^{151}$ Instead of articles like "What Does the Listener Want? Let Him Speak," 152 from May of 1927, the May 1929 issue published "How Sales and Service Are Related," 153 "Running a Small Radio Shop,”154 “The Serviceman's Corner," 155 "N.E.M.A. Attacks Service Education Problem,"156 and "In the Radio Marketplace,” industry news focusing primarily on retailers and smaller manufacturers. ${ }^{157}$

What might account for such a dramatic shift in focus and readership? One explanation is the rapid standardization and professionalization of radio. The "radio listener and enthusiast" was now two figures instead of one. With content-driven network programming, widespread radio manufacturing and retailing, and a new servicing industry, the days when being an Atwater Kent Hour listener meant knowing how to dissect one's own receiving set were probably past. Radio Broadcast's already engineering-heavy focus transformed to serve new needs, as a trade journal for radio dealers and repairmen. Meanwhile, other magazines and newspapers offered entertainment news more suitable to the new average listener.

Whatever the reason, the format change failed to keep Radio Broadcast afloat. Its publisher, Doubleday, dropped the magazine in April of 1930. It became absorbed by Radio Digest (the Radio Digest Publishing Company's flagship periodical) in September, 1930. ${ }^{158}$ That magazine folded soon after, in 1933. ${ }^{159}$

Given all this, we can conclude - beyond any reasonable doubt - that Radio Broadcast was a radio enthusiasts and listeners' magazine, not a trade journal for broadcasters, at the time the FRC took up the expansion issue. It is of course within the realm of possibility that the publication, while aimed at enthusiasts and listeners, was just a front for powerful radio broadcasters and manufacturers who wanted invisibly to influence public opinion. The editors of the magazine acknowledged at least once in 1927 that they occasionally received "rabid letters, accusing us of being bribed by the monopoly." In fact, they reprinted one of those letters, presumably to prove that it came from a crank rather than a thoughtful but concerned listener. ${ }^{160}$ Naturally, the editors denied any suggestion "that

\footnotetext{
151 15 Radio Broadcast 47.

15210 Radio Broadcast 15.

15315 Radio Broadcast 5.

${ }^{154} 15$ Radio Broadcast 10 (describing the radio retailing and servicing business).

15515 Radio Broadcast 18.

${ }^{156} 15$ Radio Broadcast 40 (reporting on radio repairmen training).

15715 Radio Broadcast 45.

${ }^{158}$ See bibliographic notes for the record "Radio Broadcast," OCLC number 1695326, in the WorldCat index of Online Computer Library Center member library collections, available at http://www.worldcat.org.

159 id.

160 This particular letter, for example, complained about "[s]ome cigarette smoking female Dago or Russian warbling in upper $\mathrm{C}$ till they drive all the dogs in the neighborhood crazy. If that is your idea of a high class programme and judging from the programmes we hear over WEAF it is just keep them in the cultured and protected east will you [sic.]" [quoted in Radio Freedom of Speech Impossible, 11 Radio Broadcast, at 139, 140 (April 1927)].
} 
these columns are subsidized."161 Other than the fact that accusing letters were apparently received on occasion, we found no hard evidence of any sort to indicate that the publication was a front. And thus we are confident that it was not. Certainly, if it was a front, then it was an extraordinarily elaborate one, given its long tenure in the publishing world, ${ }^{162}$ its high standing among radio experts, the enormous prestige of some of its leading editors and contributors (including, for example, Professor J. H. Morecroft), ${ }^{163}$ the strong criticism of broadcasters that appeared in many of its columns, and the fact the evidence of collusion has never been uncovered.

Although we doubt very much the magazine was a front for "big radio," we were able to identify several connections between the editorial board and the radio industry. Most notably, editorial board member Edgar Felix, who represented Radio Broadcast at the FRC hearings in the late March and early April of 1927, had worked as an executive at WEAF (AT\&T's station) in the early 1920s and remained a recognized expert on, and promoter of, indirect advertising (sponsorship) over the radio. ${ }^{164}$ One might reasonably conclude, therefore, that despite the criticism of broadcasters that sometimes graced its pages, the leadership of this radio enthusiasts and listeners' magazine probably did harbor some underlying sympathy for - and perhaps even identification with - leading broadcasters. Based on other pieces of evidence presented in the body of this paper, however, it seems that a great many listeners harbored similar sympathies, showing particular appreciation for the big stations, which naturally offered the best funded programming and, in most cases, the clearest signals.

\footnotetext{
${ }^{161}$ Radio Freedom of Speech Impossible, 11 Radio Broadcast, at 139 (April 1927).

${ }^{162}$ Radio Broadcast began in May 1922.

${ }^{163}$ Morecroft was professor of electrical engineering at Columbia University, a past president of the Institute of Radio Engineers, and, in general, a universally acknowledged and highly respected authority on radio. See The Institute of Radio Engineers, Aims and Activities 11, in Box 291, Commerce Period Papers, Herbert Hoover Presidential Library (1927); Columbia University Department of Electrical Engineering - History, http://www.ee.columbia.edu/history, visited July 7, 2004.

${ }^{164}$ See Smulyan, Selling Radio, 74, Erik Barnouw, The Sponsor 16 (1978). From 1922 to 1924, Edgar Felix served as WEAF's director of public relations [Edgar H. Felix, Interview 26, Radio Pioneers Project, Columbia Oral History Collection, 1962]. Towards the end of 1924, he left that job and began working at the advertising firm N. W. Ayer \& Son [Id., at 55]. In January 1927 he became a "contributing editor" to Radio Broadcast, and stayed at that position until the magazine was merged with Radio Digest in 1930 [Radio Broadcast, mastheads (January 1927-January 1929)]. During that time, he also wrote a book on the use of advertising in radio, and edited Advertising and Selling's radio section [Smulyan, Selling Radio, 74]. In an interview almost 40 years after he left WEAF, Felix suggested that his relationship with major broadcasters largely ended with his tenure at the station: "I was no longer in the middle of network broadcasting operations. [...] So the long awaited announcement of expanded network operation, the divorcement of A.T.\&T. from program and station management by the formation of the separate company to facilitate its sale to the Radio Corporation of America as the foundation for the National Broadcasting Company, was just news in the trade press to me" [Felix, Interview, 55].
} 